IDENTIFICATION OF TUMOR CELL- AND STROMA DERIVED BIOMARKERS OF TREATMENT RESPONSE IN HEAD AND NECK CANCER

\title{
Anna Ansell
}

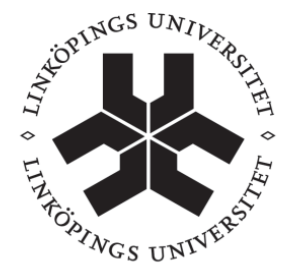

\section{Linköping University \\ FACULTY OF HEALTH SCIENCES}

Department of Clinical and Experimental Medicine

Faculty of Health Sciences, Linköping University

Linköping, Sweden

Linköping 2013 
C Anna Ansell 2013

Cover picture "Female Head" by Leonardo da Vinci

Figures $1-4$ by Jakob Domert

Published papers have been reprinted with the kind permission from the publishers

Printed in Sweden by LiU-Tryck, Linköping, Sweden, 2013

ISBN: 978-91-7519-492-9

ISSN: 0345-0082 
To my family, both two- and four-legged

"Nothing is impossible, the impossible only takes longer." Winston Churchill 


\section{SUPERVISOR}

Karin Roberg, Associate Professor

Division of Otorhinolaryngology and Head \& Neck Surgery, Department of Clinical and Experimental Medicine, Faculty of Health Sciences, Linköping University, Linköping, Sweden

\section{CO-SUPERVISORS}

Ann-Charlotte Johansson, PhD

Division of Otorhinolaryngology and Head \& Neck Surgery, Department of Clinical and Experimental Medicine, Faculty of Health Sciences, Linköping University, Linköping, Sweden

Charlotta Dabrosin, Professor

Division of Oncology, Department of Clinical and Experimental Medicine, Faculty of Health Sciences, Linköping University, Linköping, Sweden

\section{OPPONENT}

Göran Landberg, Professor

Sahlgrenska Cancer Center, Institute of Biomedicine, Göteborg, Sweden

\section{COMMITTEE BOARD}

Karl-Eric Magnusson, Professor

Division of Medical Microbiology, Faculty of Health Sciences, Linköping University, Linköping, Sweden

Lars Ekblad, Associate Professor

Department of Oncology, Lund University, Lund, Sweden

Marie Larsson, Professor

Division of Molecular Virology, Faculty of Health Sciences, Linköping University, Linköping, Sweden 


\section{ABSTRACT}

Head and neck squamous cell carcinoma (HNSCC) poses a major health problem in the world with approximately 600000 new cases yearly. Treatment resistance is a major problem within this patient group and despite advances in treatment strategies the overall survival rate has unfortunately not increased.

One of the major components of the tumor microenvironment is the cancer associated fibroblasts (CAFs) which can modulate the treatment sensitivity, tumor growth, and the invasive potential of tumor cells.

The aim of this thesis was to identify predictive markers for treatment response in HNSCC and to study the crosstalk between tumor cells and CAFs that may underlie treatment resistance.

In paper I, we identified gene expression differences between one cisplatin sensitive cell line and two cisplatin resistant cell lines, by microarray analysis, and found that a high expression of matrix metalloproteinase (MMP) -7 was associated with resistance to cisplatin. In paper II, the epidermal growth factor (EGF) receptor ligands EGF, amphiregulin, and epiregulin were evaluated regarding their potential use as predictive biomarkers for cetuximab treatment response in tongue cancer cell lines and it was shown that EGF may serve as a marker for poor cetuximab response. In paper III and IV, we investigated the influence of CAFs on the proliferation, migration, gene expression, and cetuximab response of tumor cells. It was found that CAFs induced resistance to cetuximab in a MMP-dependent manner. In addition, a microarray analysis, 
comparing tumor cells co-cultured with CAFs and tumor cells cultured alone, revealed that CAFs induced multiple gene expression changes in tumor cells some of which are related to epithelial to mesenchymal transition. Some of these changes were found to be dependent on cell-cell contact.

Taken together, we here suggest MMP-7 and EGF to be predictive markers of cisplatin and cetuximab response, respectively. We also show that CAFs protect HNSCC cells from cetuximab treatment; however, the factor responsible for the protective effect is yet to be discovered. 


\section{POPULÄRVETENSKAPLIG SAMMANFATTNING}

Cancer i huvud- halsregionen är den sjätte vanligaste cancertypen i världen och omfattar tumörer i tunga, kind, tandkött, halsmandlar, stämband, struphuvud och bihålor. Två av de största riskfaktorerna för denna cancertyp är rökning och högt alkoholintag. I kombination med varandra ökar risken för huvud- halscancer väsentligt eftersom alkohol har visats förstärka de cancerframkallande effekterna med rökning. Användandet av viss rökfri tobak, såsom t.ex. tuggtobak, ökar också risken för huvud- halscancer väsentligt, dock har inte någon ökad risk vid användning av det svenska snuset påvisats. En annan riskfaktor som har blivit uppmärksammad de senaste åren är infektion av humant papillomvirus (HPV), vilket är samma virus som orsakar cancer i livmoderhalsen. Förekomsten av huvud-halstumörer orsakade av HPV har ökat kraftigt på senaste tiden. Förändrade sexualvanor tros vara orsaken till denna ökning.

Den vanligaste behandlingen för huvud- halscancer i Sverige är strålning alternativt strålning i kombination med operation. På senare år har även cellgifter, såsom cisplatin, börjat användas i kombination med strålning och nya målinriktade behandlingar, t.ex. Erbitux, har utvecklats. Syftet med dessa nya läkemedel är att de ska påverka och/eller stänga av specifika egenskaper hos cancercellen som t.ex. cellens förmåga att dela sig och växa.

I en tumör finns inte enbart cancerceller utan även andra typer av celler som påverkar tumörens svar på behandling. En av dessa celltyper är bindvävscellerna, vilka normalt är involverade i bl.a. sårläkning och bildar ärr. I 
cancer är dock bindvävscellerna ständigt aktiva och därför brukar cancer liknas vid ett sår som aldrig läker.

Eftersom tumörerna i denna cancertyp involverar huvud- halsregionen påverkas patienternas tal- och sväljfunktion samt andning avsevärt under behandlingen, vilket gör den till en av de mest plågsamma cancertyperna. Trots att behandlingarna har förbättrats det senaste decenniet är det många patienter som inte svarar på behandlingen och därmed endast upplever de svåra biverkningarna. Därför är det väldigt viktigt att kunna urskilja de patienter som har goda förutsättningar att svara bra på en viss behandling, men även de som med största sannolikhet inte kommer att gynnas av behandlingen. Detta för att kunna välja bästa behandling för varje enskild individ samt undvika onödigt lidande hos patienterna.

Målet med denna avhandling var att för behandlingssvar hitta prediktiva markörer, d.v.s. om cancercellernas olika innehåll (t.ex. proteiner eller andra molekyler) kan förutspå vilka patienter som kommer att svara på en särskild behandling respektive inte svara på behandling. I denna avhandling visar vi att en hög mängd av ett protein som kallas matrix metalloproteinas-7 (MMP-7) är kopplat till resistens mot cisplatin, det krävs dock fler studier för att bevisa att MMP-7 kan användas som en prediktiv markör för cisplatinresistens. Som tidigare nämnt påverkar de omgivande bindvävscellerna tumörens svar på behandling och vi visar i avhandlingen att dessa bindvävsceller har god förmåga att skydda cancercellerna från den målinriktade behandlingen Erbitux. 


\section{TABLE OF CONTENTS}

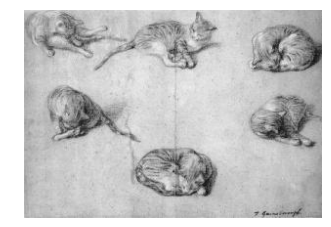

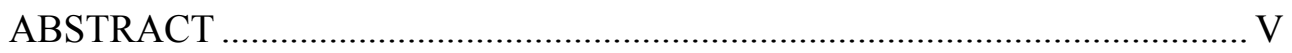

POPULÄRVETENSKAPLIG SAMMANFATTNING .................................. VII

TABLE OF CONTENTS .................................................................................

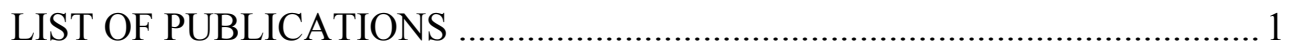

Other publications not included in this thesis ............................................. 2

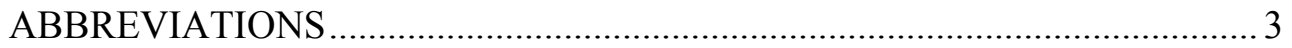

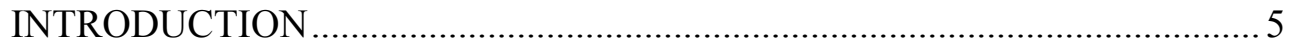

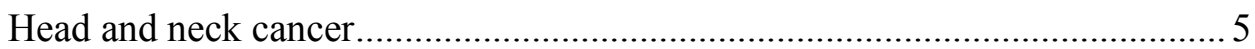

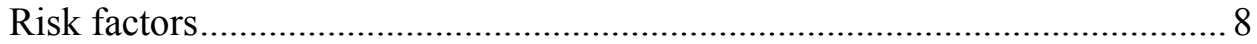

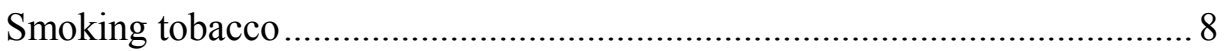

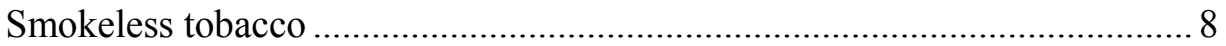

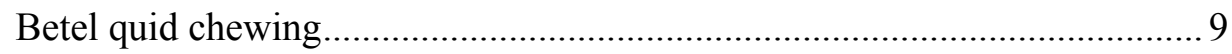

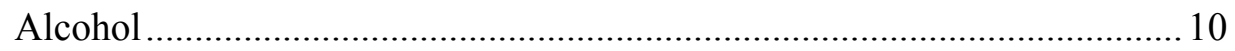

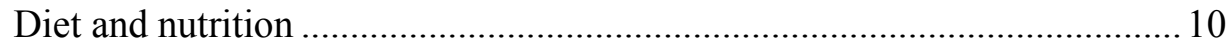

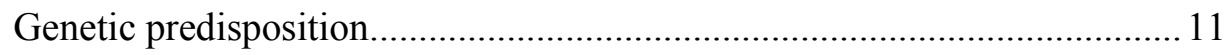

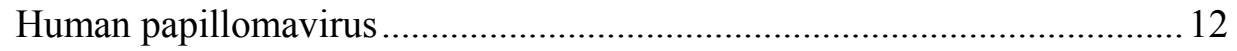

Treatments for head and neck cancer......................................................... 13

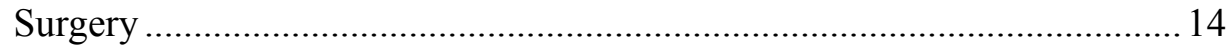

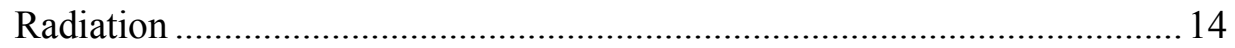

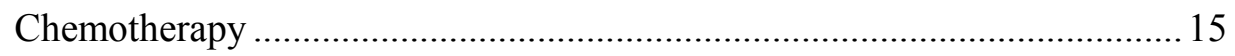

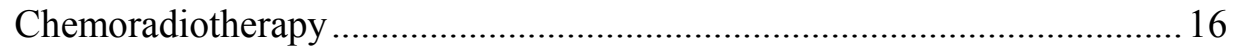

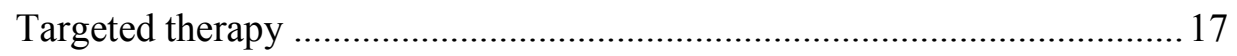




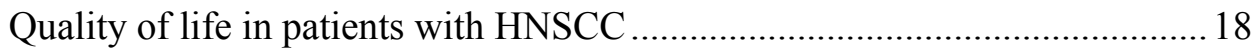

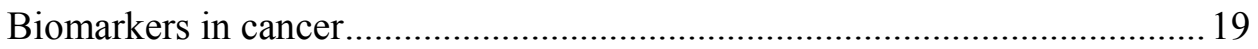

Epidermal growth factor receptor in cancer.................................................2 21

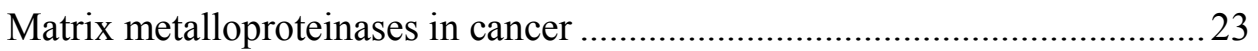

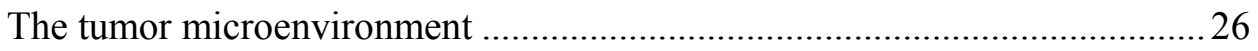

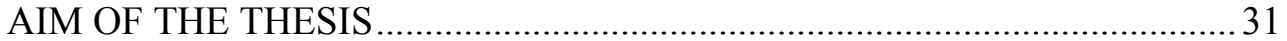

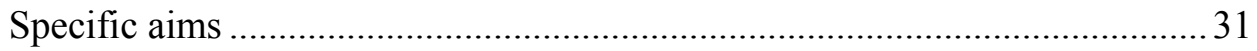

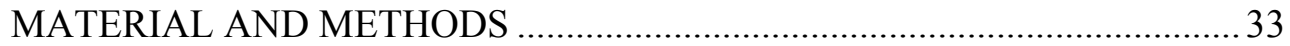

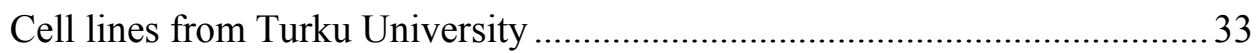

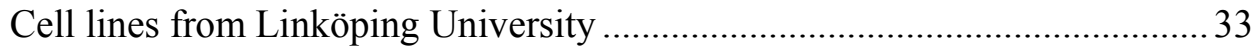

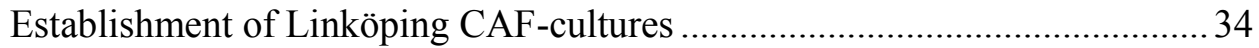

Assessment of intrinsic cisplatin- and cetuximab sensitivity ........................... 34

Co-culture systems and collection of conditioned medium............................ 35

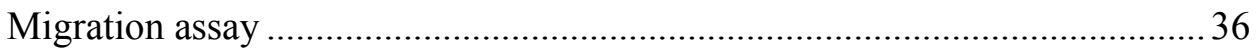

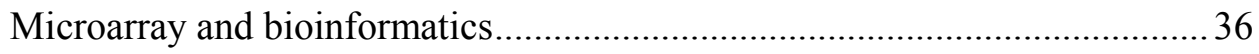

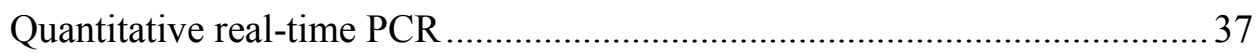

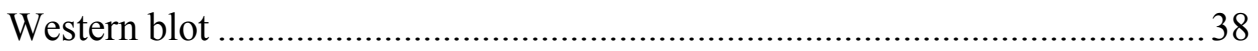

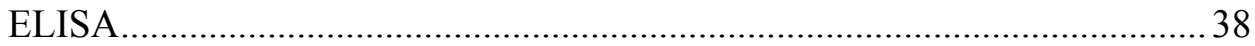

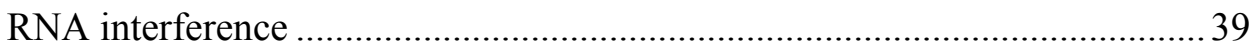

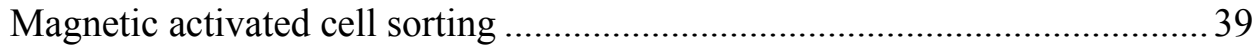

Flow cytometry and fluorescence activated cell sorting ................................ 40

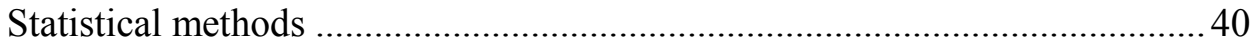

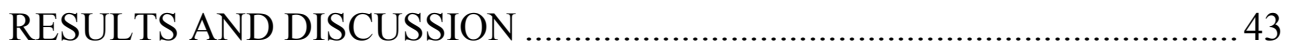

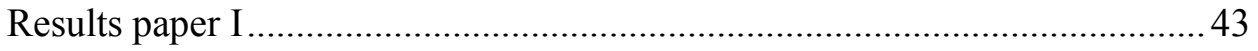

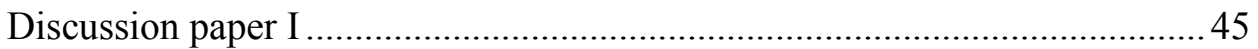

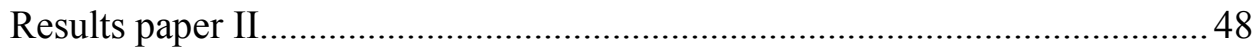

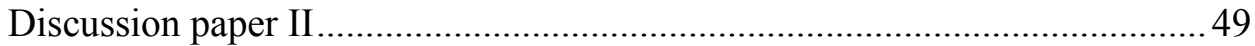

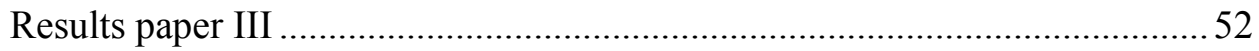




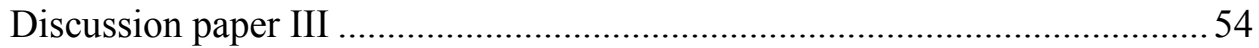

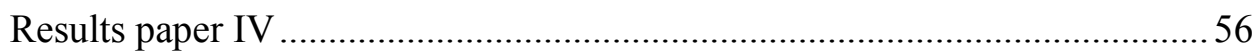

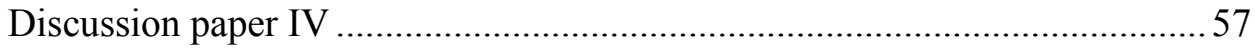

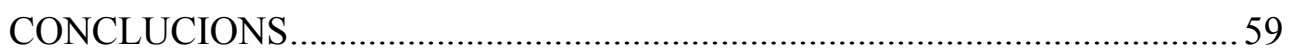

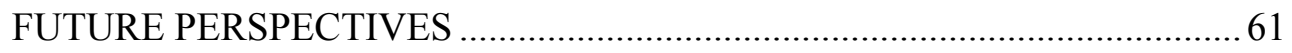

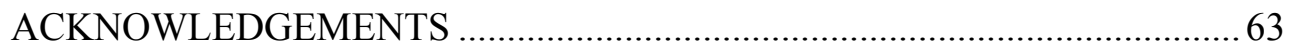

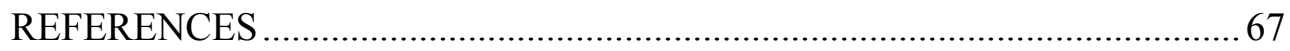





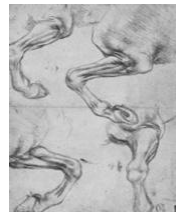

\section{LIST OF PUBLICATIONS}

This thesis is based on the following papers, which will be referred to in the text by their roman numbers I-IV:

Anna Ansell, Fredrik Jerhammar, Rebecca Ceder, Roland Grafström, Reidar Grénman, and Karin Roberg Matrix metalloproteinase-7 and -13 expression associate to cisplatin resistance in head and neck cancer cell lines

Oral Oncol. 2009 Oct;45(10):866-71.

Anna Ansell, Adam Jedlinski, Ann-Charlotte Johansson, and Karin Roberg

Epidermal growth factor is a biomarker for poor cetuximab response in tongue cancer cells

Submitted to Head \& Neck.

III Ann-Charlotte Johansson, Anna Ansell, Fredrik Jerhammar, Maja Bradic-Lindh, Eva Munck-Wikland, Reidar Grénman, Arne Östman, and Karin Roberg

Cancer-associated fibroblasts induce matrix metalloproteinasemediated cetuximab resistance in head and neck squamous cell carcinoma cells

Mol Cancer Res. 2012 Sep;10(9):1158-68.

IV Anna Ansell, Matti Kankainen, Jan-Ingvar Jönsson, Outi Monni, Karin Roberg, and Ann-Charlotte Johansson

Molecular cross-talk between head and neck squamous cell carcinoma cells and cancer-assosciated fibroblasts

Manuscript. 


\section{Other publications not included in this thesis}

1. Anna Ansell, Lovisa Farnebo, Reidar Grénman, Karin Roberg, and Lena K Thunell

Polymorphisms of FGFR4 in cancer development and sensitivity to cisplatin and radiation in head and neck cancer

Oral Oncol. 2009 Jan;45(1):23-9.

2. Lovisa Farnebo, Adam Jedlinski, Anna Ansell, Linda Vainikka, Lena K Thunell, Reidar Grénman, Ann-Charlotte Johansson, and Karin Roberg

Proteins and single nucleotide polymorphisms involved in apoptosis, growth control, and DNA repair predicts cisplatin sensitivity in head and neck cancer cell lines

Int J Mol Med. 2009: Oct;24(4):549-56.

3. Ola Wahlström, Cecilia Halling Linder, Anna Ansell, Anders Kalén, Mats Söderström, and Per Magnusson

Acidic preparations of lysed platelets up-regulate proliferative pathways in osteoblast-like cells as demonstrated by genome-wide microarray analysis

Platelets. 2011;22(6):452-60.

4. Adam Jedlinski, Anna Ansell, Ann-Charlotte Johansson, and Karin Roberg

EGFR staus and EGFR ligand expression influence the treatment response of head and neck cancer cell lines

J Oral Pathol Med. 2012: Jan;42(1):26-36.

5. Lovisa Farnebo, Katarina Tiefenböck, Anna Ansell, Lena K Thunell, Stina Garvin, and Karin Roberg

Strong expression of survivin is associated with response to radiotherapy and improved overall survival in head and neck squamous cell carcinoma patients

Int J Cancer. 2013 Oct 15;133(8):1994-2003. 


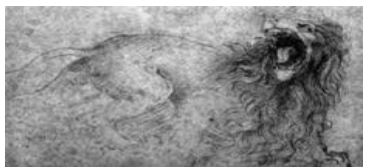

\section{ABBREVIATIONS}

AR Amphiregulin

CAF Cancer associated fibroblast

CM Conditioned medium

ECM Extracellular matrix

EGF Epidermal growth factor

EGFP Enhanced green fluorescent protein

EGFR Epidermal growth factor receptor

EMT Epithelial to mesenchymal transition

EPR Epiregulin

FACS Fluorescence-activated cell sorting

FasL Fas ligand

FBS Fetal bovine serum

FDA Food and drug administration

GOTM Gene ontology tree machine

HB-EGF Heparin-binding EGF-like growth factor

HGF Hepatocyte growth factor

HNSCC Head and neck squamous cell carcinoma

HPV Human papillomavirus

ICS Intrinsic cisplatin sensitivity

IPA Ingenuity pathway analysis

MACS Magnetic activated cell sorting

MMP Matrix metalloproteinase 
MPI Matrix metalloproteinase inhibitor

mRNA Messenger RNA

MT-MMP Membrane-type matrix metalloproteinase

NNK Nicotine-derived nitrosamine ketone

NNN $\quad \mathrm{N}^{\prime}$-nitrosonornicotine

NSAID Non-steroidal anti-inflammatory drug

NSCLC Non-small cell lung cancer

PAH Polycyclic aromatic hydrocarbons

PFA Paraformaldehyde

qPCR Quantitative real-time PCR

$\mathrm{Rh} \quad$ Recombinant human

SCC Squamous cell carcinoma

SFM Serum free medium

siRNA Small interfering RNA

SNP Single nucleotide polymorphism

ssRNA Single-stranded RNA

TIMP Tissue inhibitor of metalloproteinase

TNM Tumor, nodes, metastases

TSNA Tobacco-specific nitrosamine 


\section{INTRODUCTION}

\section{Head and neck cancer}

Head and neck cancer is a broad term referring to malignant neoplasms of the upper aerodigestive tract. ${ }^{1,2}$ These tumors are further subdivided according to the area in which they arise (Figure 1).

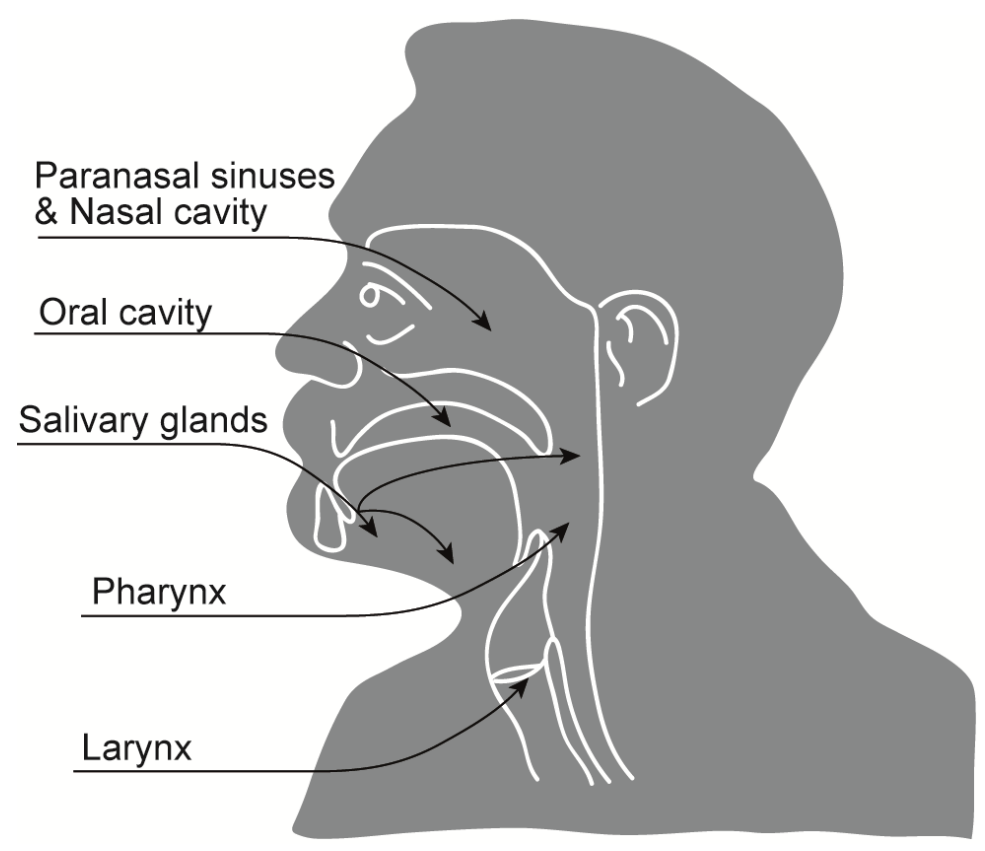

Figure 1. A schematic picture of the different sites in the upper aerodigestive tract where head and neck tumors can arise; the oral cavity (including the lips, tongue, gingiva, buccal mucosa, floor of mouth, and the hard palate), pharynx (including the nasopharynx, oropharynx, and hypopharynx), larynx, paranasal sinuses, nasal cavity, and salivary glands. 
Approximately $90 \%$ of these tumors originate from the epithelial cell layer and are thus, so-called squamous cell carcinomas (SCC), which are frequently aggressive in their biological behavior. ${ }^{2}$ Two-thirds of the patients have advanced disease with lymph node metastasis and poor prognosis. Patients with early-stage tumors have a better prognosis but unfortunately cancer in the head and neck region is usually diagnosed at a late stage.

SCC is the only patho-anatomic diagnosis studied in this thesis.

Head and neck squamous cell carcinoma (HNSCC) is the sixth leading cancer worldwide for males and the eight for women with approximately 600000 new cases and 350000 deaths every year. ${ }^{3}$ Cancer in the nasopharynx is usually separated from other HNSCC since it has a specific aetiology to Epstein-Barr virus ${ }^{4}$ and genetic factors affecting the immune response. ${ }^{5}$ However, if adding these tumors to the HNSCC group it would push head and neck cancer higher up the scale of most common cancers worldwide. ${ }^{6}$

The incidence of the different types of HNSCC displays a diverse geographical pattern worldwide. ${ }^{6}$ Due to differences in risk factors, diet, and health care among countries, two-thirds of HNSCC cases are found in developing countries. High-risk regions for cancers in the oral cavity includes Melanesia, south central Asia, western and southern Europe, Australia, and southern Africa. The enormously high risk of oral cancer in Melanesia has not been researched but data from nearby island Papua New Guinea suggest betel chewing as the major risk factor. The same risk factor causes the high prevalence of nasopharyngeal cancer in Micronesia and southeastern Asia. South central and southeastern Asia, South America, the Caribbean, and Europe, excluding the northern regions, are high risk regions for larynx cancer. These regions have high smoking prevalence explaining the high incidence of laryngeal cancer. 
There are not only ethnical differences among HNSCC cases but also differences between genders. Males are overall at higher risk to develop cancer in the head and neck region ${ }^{6}$ probably because of their more excessive use of alcohol and tobacco than females. However, studies have shown that women who are smoking have a larger increased risk of developing HNSCC than males who are smoking. ${ }^{7}$ The mechanisms underlying these differences are not yet fully understood but hormonal risk factors could be involved. Indeed, estrogen deficiency has been shown to increase the risk for oral cancer among women. ${ }^{8,9}$

The typical HNSCC patient is a 65 year old male with low socioeconomic status and heavy alcohol and smoking habits. However, an alarming trend has been noticed the past years with an increasing number of individuals younger than 45 years of age developing HNSCC. ${ }^{10,11}$ It is not clear why this increased incidence among young adults occur. Some case reports have though come to the conclusion that the risk factors present in older patients were similar to the ones in younger patients ${ }^{11,12}$ and that early exposure of the oral epithelium to risk factors such as tobacco and alcohol may shorten the latency period in carcinogenesis. ${ }^{13}$ As noticed, the highest risk for developing oral cancer among young adults was onset of smoking and excessive drinking under the age of 16 years. ${ }^{12}$ In other parts of the world where the prevalence for head and neck cancers are high many individuals who are less than 40 years old develop cancer owing to cultural practices with early onset of use of different forms of tobacco. On the other hand, there is a distinct patient group, encompassing primarily younger females, which have little or no exposure to any major risk factors. ${ }^{14-16}$ This group calls for further studies but genetic susceptibility ${ }^{17}$ and younger mean age at menopause, leading to estrogen deficiency, have been suggested as risk factors. ${ }^{8,9}$ In recent years, the human papillomavirus (HPV) type 16 has been 
associated with cancer in the tonsils and base of tongue in a subset of younger patients with no other reported risk factors. ${ }^{18,19}$

\section{Risk factors}

One of the most important risk factors for HNSCC is tobacco ${ }^{20}$ which can be consumed in many different forms; cigarettes, cigars, beedi, oral snuff, or in moist pouches (used in northern Scandinavia). ${ }^{21}$

\section{Smoking tobacco}

Smoking tobacco is a worldwide problem with nearly 1.3 billion users. ${ }^{22}$ Cigarette smoking is strongly associated with oral, larynx, and pharynx cancer. ${ }^{23}$ To date, more than 60 carcinogenic products have been found in cigarettes. Tobacco-specific nitrosamines (TSNAs), which include nicotine-derived nitrosamine ketone $(\mathrm{NNK})$ and $\mathrm{N}^{\prime}$-nitrosonornicotine $(\mathrm{NNN})$, and polycyclic aromatic hydrocarbons (PAH) are the most carcinogenic products found in cigarettes and also the most causative agents for oral, larynx, and pharynx cancer. NNK, NNN, and PAH contribute to the development of cancer by formation of DNA adducts. ${ }^{24}$ In a normal state, the cellular repair system removes the DNA adducts, but if this system is malfunctioning mutations may arise e.g., PAH has been associated with mutations in the tumor suppressor gene p53 leading to larynx cancer. Oxidative stress can be caused by cigarette smoke due to the content of free radicals such as nitric oxide. Free radicals are known to damage proteins, lipids, and DNA. ${ }^{25,26}$

\section{Smokeless tobacco}

Smokeless tobacco is a significant and growing problem worldwide and there are many different types of products. In contrast to smoking tobacco, smokeless tobacco contains around 16 carcinogenic products and the levels of PAH are 
quite low. ${ }^{27}$ However, the NNKs and NNNs are hundreds to thousands times higher than in cigarettes and are the most important agents in the development of oral cancer in smokeless tobacco users. As recently noticed, NNK together with nicotine binds to different cell surface receptors such as the nicotinicacetylcholine receptor, thus activating the AKT-pathway, leading to decreased apoptosis and increased cell proliferation. Conversely, the moist pouches used in northern Scandinavia have a lower content of TSNAs and it has been suggested as a nicotine replacement in smokers who are having difficulties in smoking cessation. ${ }^{28,29}$ This is however, highly controversial since no safe tobacco exists to date.

Since tobacco is the most important cause of cancer and cancer-related deaths, it has been used as a model for understanding the mechanisms of cancer development.

\section{Betel quid chewing}

Betel quid and areca nut chewing are practiced by 600 million people worldwide. ${ }^{30}$ It is widespread in many parts of Asia and among Asianimmigrants in other parts of the world. A betel quid is commonly composed of betel leaf from the Piper betel vine, areca nut from the Areca catechu tree, slaked lime (calcium hydroxide), and spices according to local preferences. The betel quid may also include tobacco. The areca nut contains at least four chemical alkaloids whose nitrosamine derivatives have been found to be carcinogenic. ${ }^{31}$ Approximately $40 \%$ of all areca nut samples are contaminated with the fungus Aspergillus flavus ${ }^{32}$ which contributes to poor oral hygiene. Subjects with poor oral hygiene have an increased formation of endogenous nitrosamines $^{31}$ and this enhances the amount of nitrosamines upon betel quid chewing. ${ }^{33}$ As seen in tobacco smoking, betel quid chewing can also cause 
oxidative stress. ${ }^{25}$ In addition, slaked lime causes erosions of the oral mucosa and this facilitates the infiltration of betel quid carcinogens. ${ }^{34}$

\section{Alcohol}

One of the other major risk factors for oral cancer is alcohol consumption. ${ }^{35-37}$ Alcoholic beverages are usually composed of ethanol and water and although ethanol itself is not carcinogenic, acetaldehyde, a metabolite of ethanol, has mutagenic and carcinogenic effects. ${ }^{38}$ When acetaldehyde is produced from ethanol by mucosal alcohol dehydrogenase in the oral epithelium it interferes with DNA synthesis and repair which may lead to mutations. ${ }^{35,39}$ Alcohol is also known to greatly enhance the risk for oral cancer when it is used together with tobacco. ${ }^{40-42}$ Alcohol may render the tissue more sensitive to tobacco carcinogens either by increasing their solubility ${ }^{39}$ or by increasing the permeability of the oral mucosa. ${ }^{43}$ Furthermore, smokers were found to have increased amounts of gram-positive bacteria, capable of producing acetaldehyde from ethanol, in their oral epithelium. ${ }^{44,45}$ This may also contribute to the synergistic effect between alcohol and tobacco.

Whether mouthwashes containing alcohol might be a risk factor for oral cancer is an interesting question. However, so far epidemiological studies have not found a link between the use of alcohol-containing mouthwashes and oral cancer. $^{46,47}$

\section{Diet and nutrition}

Dietary factors are the cause of $30 \%$ of all cancers in the world ${ }^{48}$ and it is also one of the most important risk factors for HNSCC of all sites ${ }^{49-51}$ together with tobacco and alcohol. High intake of fresh fruits and especially citrus fruits, vegetables, fish, and vegetable oils has been associated with a low risk of developing HNSCC. ${ }^{49}$ All of these are rich in vitamins A, C, and E, beta- 
carotene, and selenium. These micronutrients have antioxidant effects and reduce free radical reactions. ${ }^{52,53}$ However, high intake of micronutrients does not decrease the risk of developing HNSCC due to smoking and alcohol consumption. ${ }^{54}$ There are many differences in diets between ethnical groups due to cultural food habits. In addition, there are also large cultural differences when it comes to the use of risk factors. For example, there are more blacks than whites suffering from HNSCC in the USA. Studies revealed that blacks tended to use alcohol and tobacco to a higher extent and that the intake of fresh fruits were much lower among the blacks. ${ }^{41,42}$ Furthermore, it has been shown that smoking and alcohol drinking reduce the levels of beta-carotene and vitamin $\mathrm{C}$ in serum. ${ }^{55-57}$ Speculatively, heavy drinkers may also have nutritional deficiencies due to decreased micronutrient intake, or weakened absorption. During betel quid chewing lower levels of vitamins A and C, and beta-carotene have also been noticed. ${ }^{58}$ However, if the betel quid contained betel leaves, betel chewers were found to have high levels of beta-carotene. This may be explained by the fact that betel leaves contain several phenols which have antioxidant effects and might to some extent be protective.

\section{Genetic predisposition}

Since not all smokers or heavy drinkers develop HNSCC, exposure to carcinogens cannot alone fully account for the development of cancer and it has been suggested that some individuals may have an inherited genetic susceptibility to HNSCC. ${ }^{17}$

Although inherited HNSCC is not very common there is evidence for inherited genetic predispositions causing HNSCC. These inherited genetic alterations can either be conditions with a predisposition to cancer such as Fanconis anaemia, dyskeratosis congenita, and Cowden syndrome $e^{59,60}$ or multiple single nucleotide polymorphisms (SNPs) which cause DNA damage, activation of oncogenes, 
inactivation of tumor suppressor genes, loss of function in the DNA repair system, or impaired carcinogen-metabolizing enzyme systems such as the cytochrome P450 and the glutathione S-transferase mu $1 .{ }^{61-63}$ All these genetic alterations lead to genomic instability, the most constant characteristic of cancer.

\section{Human papillomavirus}

As previously mentioned, an increase of younger patients developing HNSCC has emerged the past few decades and an increase of oropharyngeal cancers, i.e., cancer of the tonsils and base of tongue, have been noticed within this younger patient group and especially in men. ${ }^{64,65}$ These patients commonly report no history of tobacco or alcohol use so other risk factors may have contributed to the observed trend. Indeed, this malignancy has recently been reported to be associated with HPV and mainly HPV type $16 .{ }^{19}$ A large multi-center study has shown that more than $25 \%$ of all HNSCC contain HPV genomic DNA ${ }^{66}$ and that $72 \%$ of all oropharyngeal cancers are HPV-positive. ${ }^{19}$ However, here in Sweden the incidence of HPV-positive oropharyngeal cancers is much greater. ${ }^{67,68}$ Researchers at Karolinska Institute have shown that the proportion of HPVpositive tonsillar cancers has increased from 68\% during the years 2000-2002 to 93\% during 2006-2007. ${ }^{67}$ This increased incidence of HPV-positive tumors may be explained by changes in sexual norms such as having more oral sex partners or having oral sex at an earlier age. In addition, the prevalence of HPV is higher in cervical cancers than in penile cancers, making the speculation that performing oral sex on women boosts the risk for HPV infections in men. Thus, men have a higher rate of HPV associated oropharyngeal cancers. A recent study has also shown that individuals with reported poor oral health had a $56 \%$ higher prevalence of HPV-infections. ${ }^{69}$ A poor oral hygiene may include ulcers or inflammations in the gingiva and this might facilitate the entry of HPV since this virus usually requires wounds to establish infections. 
High-risk HPV such as HPV type 16 mediate their carcinogenic effect through the action of the two viral oncogenes E6 and E7. ${ }^{70}$ E6 binds and forms a complex with p53 which results in p53 degradation ${ }^{71}$ while E7 destabilizes the $\mathrm{Rb}$ tumor suppressor protein. ${ }^{72}$ Both of these events result in defects in apoptosis, DNA repair, and cell cycle control and this leads down the pathway towards malignancy.

Two vaccines for prevention of HPV-related diseases have been developed: Cervarix ${ }^{\circledR}$ (Glaxo Smith Kline), which is a vaccine against HPV type 16 and HPV type 18, and Gardasil ${ }^{\circledR}$ (Merck \& Co) which is also protective against HPV type 16 and HPV type 18 . In the future it will be very interesting to see if these new vaccines will protect not only against cervical cancer but also against HPV-positive HNSCC.

\section{Treatments for head and neck cancer}

Despite advances in surgical and oncological treatments that enhance quality of life the overall survival rate has unfortunately not increased over the past decades and clinical drug resistance remains a major problem in HNSCC. ${ }^{73}$ The difficulties in HNSCC treatment might be explained by the high heterogeneity within the group of HNSCC tumors. Tumors of the oral cavity (including lips, tongue, gingiva, buccal mucosa, floor of mouth and the hard palate), pharynx, larynx, and paranasal sinuses all belong to the same group of cancers despite their differences in location, cause and/or function. These differences may also cause the complexity in finding markers predictive for treatment responses. To date, factors that influence the choice of treatment are the characteristics of the primary tumor which include, TNM (tumor, nodes, metastases) -stage, location, proximity to bone, and histological grading of the tumor. ${ }^{74}$ In addition, factors related to the patient including age, general medical condition (which might 
affect the tolerance of treatment), lifestyle (smoking, drinking and other socioeconomic difficulties), and acceptance by the patient are also taken into consideration when determining the initial treatment. Expertise within the team of physicians is also an important factor in making treatment decisions since managing HNSCC is a multidisciplinary team effort. Knowledge in surgery, radiotherapy, chemotherapy, rehabilitation, dental-, and psycho-social support all play an important role in the treatment selection.

The curative management for locally advanced HNSCC in stages III or IV is more difficult than for early stage HNSCC (stage I or II). Stage III or IV disease is associated with a decrease in loco-regional control, an increase in distant metastasis, and a shorter disease-free survival, and generally demands more intense treatment when compared to early stage disease.

\section{Surgery}

Surgery is considered to be the standard treatment for HNSCC patients with early stage I or II cancer in the oral cavity. ${ }^{1}$ However, the anatomical location of head and neck tumors makes surgery a challenge since major functions such as swallowing and speech are affected by the treatment. ${ }^{75}$ In the past decade organ preservation methods such as microvascular free-flaps, which aims to maintain these functions, have increased. ${ }^{2,76}$

\section{Radiation}

Radiation is the standard treatment for HNSCC patients with early stage I or II oropharyngeal and hypopharyngeal cancers. ${ }^{1}$ For managing locally advanced HNSCC (stage III or IV) the primary mode of treatment is surgery in combination with pre- or post-operative radiation. Since the overall survival after radiation is less than $25 \%{ }^{77,78}$ a number of efforts have been made to improve these disappointing results. Two altered fractionation radiotherapies, 
hyperfractionation and accelerated fractionation, have been introduced, however, the results have not been ground-breaking. ${ }^{79-81}$ Many factors such as smoking habits during treatment, hemoglobin levels, hypoxia levels, and tumor location have been implicated to affect the radiation treatment outcome. ${ }^{82}$

The exposure of cells to ionizing radiation leads to DNA damage through the formation of reactive oxygen species that chemically react with DNA. ${ }^{83}$ The most severe damage is the double-strand break, which results in cell cycle arrest, apoptosis, gene inactivation, reproductive failure, or terminal senescence.

\section{Chemotherapy}

Chemotherapies such as cisplatin, carboplatin, docetaxel, gemcitabine, and fluorouracil have evolved from being used in palliative care to be used also as curative components in the treatment of locally advanced HNSCC. ${ }^{84}$ However, cisplatin is the most common and effective chemotherapeutic drug used in the treatment of locally advanced HNSCC. It was discovered by accident in 1965 when Barnett Rosenberg applied electromagnetic radiation using platinum electrodes to Escherichia coli and saw that the bacteria filaments grew up to 300 times their normal length. ${ }^{85,86}$ The cell growth was continued during the radiation through the platinum electrodes but the cell division was inhibited. What they realized after this experiment was that they had rediscovered a platinum coordination complex, known as Peyrone's chloride, that was originally synthesized and described in $1845 .^{87}$ The effect on cell division was later verified in a sarcoma mouse model where cisplatin caused marked tumor regression. $^{88}$

Cisplatin exerts its anti-cancer effects by binding covalently to DNA and forming DNA adducts which results in activation of DNA repair, cell-cycle arrest, and apoptosis. ${ }^{86}$ Clinical resistance to cisplatin is a significant problem 
for patients with locally advanced HNSCC and only $20-30 \%$ of the patients respond to this treatment. ${ }^{89}$ Numerous cellular mechanisms have been implicated in resistance to cisplatin and these include decrease in cellular drug accumulation, increased DNA repair, increased levels of intracellular thiols (e.g., glutathione or metallothionein) that binds to cisplatin and causes deactivation, and increased expression, mutations, or deregulation of antiapoptotic genes. ${ }^{90-93}$

Cisplatin has very severe side-effects including nephrotoxicity, ototoxicity, neutropenia as well as nausea and vomiting, ${ }^{94}$ which all cause a lot of pain and distress within the patient. Speculatively, it is not clear whether cisplatin would even be approved if it was to be presented to regulatory authorities today.

\section{Chemoradiotherapy}

As previously mentioned, locally advanced HNSCC (stage III or IV) have a more aggressive behavior and require more intense treatments in order to achieve loco-regional control. The introduction of concurrent administration of chemotherapy and radiotherapy has been a major advancement for late stage disease. ${ }^{1}$ Although several phase III clinical trials have shown that chemoradiotherapy improve loco-regional control, the absolute survival benefits noticed in these studies are relatively small and can in general be explained by the improved loco-regional control. ${ }^{95-101}$ Meta-analyses of clinical trials have showed that chemoradiotherapy compared to radiotherapy alone gave a slight increase in absolute survival benefit of $4-8 \%$ at 5 years however; this was related to increased toxicity including mucositis, dermatitis, and myelosuppression. ${ }^{102-104}$ Nevertheless, these toxic effects are overshadowed by the paramount importance to cure the patients and chemoradiotherapy is nowadays a standard treatment for locally advanced HNSCC. ${ }^{105}$ 


\section{Targeted therapy}

Targeted therapies are a promising field in cancer managements and they are usually targeting growth factor receptors and their downstream signaling. One such receptor is the epidermal growth factor receptor (EGFR) which is overexpressed in more than $90 \%$ of all HNSCC. ${ }^{106}$ Moreover, EGFR expression is associated with poorer survival and loco-regional failure. Due to the relationship between the overexpression of EGFR and the aggressive behavior of locally advanced HNSCC, therapies aiming to prevent EGFR signaling, including monoclonal antibodies and small molecule tyrosine kinase inhibitors have been developed. The monoclonal antibody cetuximab (Erbitux ${ }^{\circledR}$, Merck $\mathrm{KGaA}$ ) was in 2006 approved by the Food and Drug Administration (FDA) to be used in combination with radiotherapy as a first-line treatment for patients with loco-regionally advanced HNSCC. ${ }^{107,108}$ Cetuximab has also been approved for recurrent or metastatic HNSCC both as first-line treatment in combination with platinum-based chemotherapy, ${ }^{109-112}$ and as second-line treatment in platinum-refractory patients. ${ }^{113-115}$ Although cetuximab has shown promising results in HNSCC clinical trials the response rate is generally not higher than $20 \%{ }^{107,110,116,117}$ KRAS mutations, which are well-established markers of cetuximab resistance in colorectal cancers, ${ }^{118}$ are rarely present in HNSCC tumors; ${ }^{119}$ therefore, this marker has not proven useful for the selection of HNSCC patients to receive cetuximab treatment.

Cetuximab is associated with skin toxicity and the typical side-effects include rashes and changes to the hair and nails. ${ }^{106}$ Following administration, cetuximab binds to the extracellular domain of EGFR and prevents ligand binding. ${ }^{120-122}$ In addition, it may also stimulate the internalization of EGFR, which leads to the downregulation of its cell surface expression, and may also trigger antibodydependent, cell-mediated cytotoxicity. ${ }^{123}$ 
Since the side-effects during cetuximab treatment are not that severe it is used in combination with radiation for locally advanced HNSCC in patient who are not good candidates for cisplatin.

\section{Quality of life in patients with HNSCC}

Of all human cancers, HNSCC is the most devastating one causing a great deal of pain and suffering for the patients. As previously mentioned, patients with HNSCC and especially those with late stage disease have a high risk of treatment failure and if cured, they are facing disfigurement, loss of speech, and impairment of the basic survival functions of breathing and swallowing. This results in serious medical and psychosocial consequences and many patients may be at risk for severe depression or even worse, suicide. It is very important to capture the patient's point of view following HNSCC disease and treatment since that may differ from the physicians' opinion. In recent years, quality of life data has been used as a tool for measuring the patient's perspective. ${ }^{124}$

Due to the anatomical location of HNSCC tumors the patient's smell, taste, speech, and ability to swallow may be disrupted before, during, and after treatment. Xerostomia, or dry mouth, is a major problem after radiotherapy and it has been shown that patients suffering from xerostomia also have a greater impairment in swallowing and speech performances. Pain is a specific concern within HNSCC patients and may arise as a result of many factors such as tumor ulcerations, tumor pressure effects, nerve infiltration, treatment-related pain due to radiotherapy and chemotherapy, postoperative wounds, shoulder dysfunction, or osteoradionecrosis. It is heartbreaking that many patients do not respond to the different treatments since these are responsible for the many sufferings mentioned above and this is why the search for markers that will predict treatment outcome is so important. 


\section{Biomarkers in cancer}

A biomarker can either have a prognostic or a predictive value, or both. A prognostic marker foretells the risk of recurrence or survival in the absence of treatment or during the use of a standard therapy whereas a predictive marker guides the treatment decision since it predicts the outcome of specific treatments. An ideal biomarker would have both a prognostic and a predictive value and would also serve as a therapeutic target.

Numerous proteins and genetic markers (e.g., mutations, SNPs, and gene copy number) involving cell cycle control, apoptosis, and growth regulation have been proposed to refine clinical outcome and predict treatment outcomes in several cancer types over the past decade. Measurement of hypoxia and the detection of viral DNA have also been proposed as potential biomarkers. However, very few of these markers are in routine clinical use and it is unlikely that one single marker could truthfully predict response to treatment or have a prognostic value. How tumor cells progress and respond to treatments are very complex and involves many different deregulated pathways. Hence numerous markers have to be combined in order to predict survival and treatment outcome in cancer patients.

To date, no predictive marker or panel of markers has been validated to be used in the clinic for selection of treatment options for patients with HNSCC. In contrast, for colorectal cancers KRAS mutation status is predictive for the selection of patients receiving cetuximab ${ }^{118}$ but this is not an option for HNSCC since these mutations are very rare in this disease. ${ }^{119}$ In addition, the estrogen receptor and progesterone receptor are used as predictive markers for selecting breast cancer patients likely to respond to hormone therapy. ${ }^{125}$ Another predictive marker used in metastatic breast cancer is the gene amplification or 
overexpression of human epidermal growth factor receptor 2 (HER2) which identifies individuals who may benefit from trastuzumab. ${ }^{126-128}$ HER2 belongs to the same subclass of receptor tyrosine kinases as EGFR $^{129}$ but gene amplification or overexpression of EGFR are not predictive for cetuximab treatment outcome in HNSCC. ${ }^{130,131}$ On the contrary, a high EGFR expression has been shown to predict survival benefits in patients with advanced non-small cell lung cancer (NSCLC) who receive cetuximab in combination with first-line chemotherapy. ${ }^{132}$ Nevertheless, in HNSCC patients, a high EGFR expression has been associated with poor prognosis and decreased overall survival and is therefore used as a prognostic marker in HNSCC. ${ }^{133,134}$ One hypothesis as to why EGFR expression is not predictive of cetuximab treatment outcome is that clinical doses of cetuximab may not achieve receptor saturation within tumors with high EGFR expression. Furthermore, in a study where EGFR expression was determined by immunohistochemical analysis it was shown that tumors with less than $80 \%$ cellular EGFR positivity had a better response to cetuximab. ${ }^{112}$ Interestingly, to date, the strongest biomarker for cetuximab treatment response in HNSCC is the clinical observation of skin rashes and not a laboratory-based assay. ${ }^{112}$ Patients with skin rashes have a much better response to cetuximab treatment than patients who do not develop skin toxicities. However, this biomarker is only predictive during treatment and is therefore impossible to use as a predictive marker before treatment.

HPV type 16 is now also recognized as a prognostic marker for survival outcome in HNSCC; patients with HPV-positive tumors have a better prognosis than patients with HPV-negative tumors. ${ }^{135}$ This is likely due to the fact that the biology of HPV-associated tumors is different from that of tobacco-associated HNSCC. For example, tobacco-related HNSCC is associated with loss of p16 and overexpression of cyclin D1 ${ }^{136,137}$ whereas, in HPV-related HNSCC, 
overexpression of p16 and low levels of cyclin D1 is documented. ${ }^{138}$ Inactivation or deletion of p16 and overexpression of cyclin D1 have been associated with poor prognosis, reduced survival, and impaired response to treatment. ${ }^{136,139}$ What is more, patients with HPV-positive tumors seem to be more responsive to both radiotherapy and chemotherapy ${ }^{140}$ however, the use of HPV type 16 as a predictive marker for treatment outcome in HNSCC has not yet been proven. The overall better prognosis regardless of the treatment regimen for HPV-positive HNSCC compared with HPV-negative HNSCC seems to be related to the immune system rather than the tumor cells' intrinsic sensitivity to the treatments. ${ }^{141,142}$

The lack of predictive markers in HNSCC is worrying and a great challenge for researcher within the field. HNSCC is a very heterogeneous disease which hampers accurate prognostication, treatment planning, and, from a biomarkers point of view, the identification of causative cancer genes. The increased availability of high-throughput screening methods and the combinations of other molecular analyses will hopefully lead to the discovery of markers associated with prognosis and treatment outcome in HNSSC.

\section{Epidermal growth factor receptor in cancer}

EGFR is overexpressed in approximately $30 \%$ of all human epithelial tumors ${ }^{143}$, including HNSCC, of which nearly all tumors exhibit EGFR overexpression. ${ }^{144}$ EGFR is a transmembrane tyrosine kinase cell surface receptor that belongs to the ErbB family, which consists of four closely related receptors: EGFR (ErbB1/HER1), ErbB2 (HER2), ErbB3 (HER3), and ErbB4 (HER4). ${ }^{129,145}$ Upon ligand binding, these receptors (except for HER2 which has no known ligand ${ }^{146}$ ) form either homo- or heterodimers, which results in activation of the intracellular tyrosine kinase domain. ${ }^{147}$ The EGFR/HER2 heterodimer is more 
highly expressed on the cell surface than EGFR/EGFR homodimers and it is also more stable, leading to a prolonged activation period. ${ }^{148,149}$ The subsequent triggering of several downstream signaling pathways, including MAPK, PI3K/Akt, JAK/Src/STAT, and PLC $\gamma$, leads to the transcription of genes associated with proliferation, migration, and survival. ${ }^{150,151}$

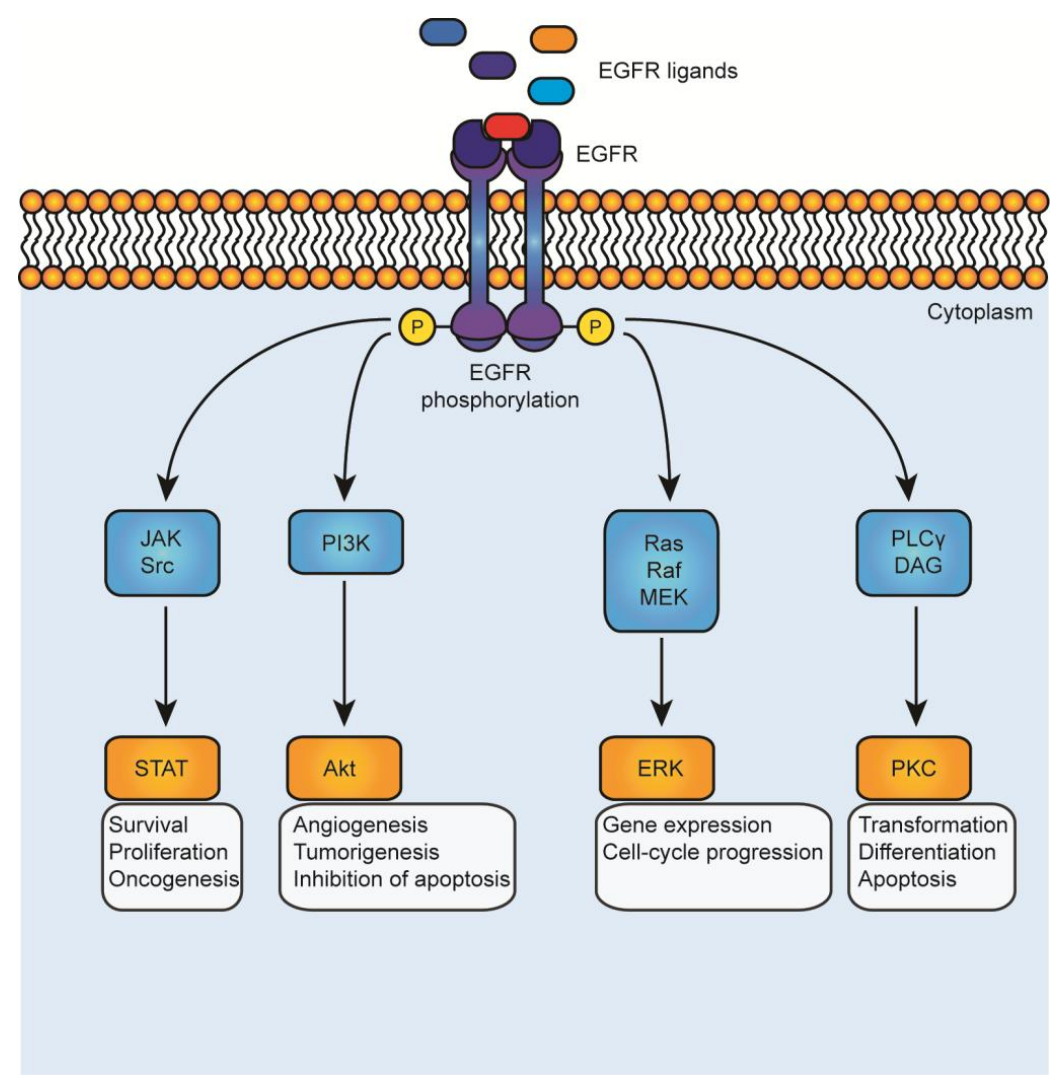

Figure 2. Upon ligand binding the epidermal growth factor receptor (EGFR) dimerizes, which leads to the autophosphorylation and activation of the intracellular tyrosine kinase domain. This leads to triggering of multiple downstream signaling pathways including MAPK, PI3K/Akt, JAK/Src/STAT, and PLCY.

There are seven known EGFR ligands: epidermal growth factor (EGF), amphiregulin (AR), epiregulin (EPR), betacellulin, epigen, transforming growth 
factor- $\alpha$, and heparin-binding EGF-like growth factor (HB-EGF). ${ }^{152}$ These ligands are secreted by tumor cells and participate in auto- and paracrine stimulation. ${ }^{153}$

Why some tumors do not respond to treatment with the monoclonal EGFR antibody cetuximab is not completely understood but numerous underlying mechanisms have been proposed during the years. The EGFR variant III, which is a truncated form of EGFR that lacks the ligand binding domain and is constitutively active, has been shown to contribute to both cetuximab and cisplatin resistance. ${ }^{154}$ The formation of EGFR heterodimers and/or crosstalk with HER2, HER3, cMET, and insulin-like growth factor 1 receptor might also be responsible for resistance to cetuximab. ${ }^{155}$ Other mechanisms include upregulation of EGFR ligands ${ }^{156-163}$ and higher expression of nuclear EGFR than membrane EGFR. ${ }^{164}$ Epithelial to mesenchymal transition (EMT) was first implicated in resistance to cetuximab in hepatocellular carcinoma and urothelial carcinoma ${ }^{165,166}$ and current evidence show that also HNSCC cells may utilize EMT in order to evade cetuximab treatment. ${ }^{167,168}$ This is likely due to lower EGFR expression (which leads to decreased EGFR-dependent survival signals) on mesenchymal-like cells. ${ }^{167}$

\section{Matrix metalloproteinases in cancer}

The matrix metalloproteinase (MMP) family is a diverse group of approximately 23 different zinc-dependent endopeptidases which are synthesized as latent enzymes and are activated after release of their propeptide domains. ${ }^{169,170}$ The majority of MMPs are secreted proteins but an exception is the membrane-type metalloproteinases which are attached to the cell surface. The MMPs are further grouped into collagenases, gelatinases, stromelysins, matrilysins, membranetype MMPs (MT-MMPs), and others. ${ }^{170}$ Their local activity in tissues is 
regulated by the expression of endogenous tissue inhibitors of metalloproteinases (TIMPs). Four TIMPs (TIMP-1, TIMP-2, TIMP-3, and TIMP-4) have been identified and TIMP-1 and TIMP-2 are commonly detected in HNSCC. Changes of TIMP levels during pathological conditions such as cancer are considered to be important since they directly affect the level of MMP activity.

MMPs have for a long time been considered as critical for tumor progression, invasion, and distant metastasis. ${ }^{171}$ At first, the understanding of MMP action in tumor progression and invasion was very simple; tumor cells produced and secreted MMPs in order to degrade the various components of the extracellular matrix (ECM) and thereby facilitate tumor cell spread to local and distant sites. However, our understanding has changed over the past years. It is now known that MMPs also have substrates unrelated to ECM components and that it is primarily the cleavage of these non-matrix substrates (e.g., chemokines, growth factors, growth factor receptors, integrins, and apoptotic mediators) that leads to tumor progression and invasion. Thus, MMPs contribute to the formation of a complex microenvironment that promotes malignant transformation in early stages of cancer. ${ }^{172,173}$ Furthermore, it is also recognized that MMPs are synthesized not only by tumor cells but also by many other cell types within the tumor microenvironment such as endothelial cells, fibroblasts, and infiltrating immune cells. ${ }^{174,175}$

There is no doubt that MMPs play an important role in cancer progression, invasion and metastasis and this has led to the clinical development of multiple MMP inhibitors (MPIs). ${ }^{171}$ Unfortunately, none of these MPIs showed positive results in phase II and III clinical trials. What is now known is that the development of MPIs in the 1990's had to overcome multiple unpredicted problems. First, at that time it was still unknown if specific MMPs played 
important roles in different cancer types and the rapidity in which MPIs moved into clinical trials did not allow for expression analysis of the entire MMPfamily in the specific cancer type used for clinical trials. For example, the MPI tanomastat, which targets MMP-2 and has very low activity toward MMP-11, should never have been tested in patients with non-small lung cancer since in this cancer type, high MMP-11 is associated with poor prognosis and MMP-2 is not detected. This particular trial was terminated early because tanomastattreated patients showed poorer survival than placebo-treated patients. Another problem with the hasty progression of MPIs from phase I studies into phaseII/III combination clinical trials was that the information regarding the benefit of efficacy from smaller studies was lost. Early phase I studies revealed that prolonged treatment with MPIs caused musculoskeletal pain and inflammations, thus clinical dosage of MPIs was determined due to these side effects rather than efficiency on tissue penetration or inhibition activity. It has been shown that inhibition of related metalloproteinases such as ADAMs and ADAMTSs are responsible for the side effects observed during administration of these broad spectrum MPIs. ${ }^{176}$ Lastly, these clinical trials excluded patients with early stage cancer since the selection was based on the criteria for conventional chemotherapy. This is contradictive since MPIs seems to be more efficient in early stage cancer ${ }^{177,178}$ and that MMPs play an important role in early cancer development as well. ${ }^{172,173}$ MPIs are cytostatic drugs and should, therefore, not be compared with cytotoxic drugs.

MPIs were one of the first targeted therapies designed and tested in clinical trials but the outcome has been very disappointing. Many problems with these clinical trials have been brought to light but a wider understanding of the role of specific MMPs in tumors and the design of specific MPIs which do not have dose-limiting musculoskeletal side effects are wished for. One new possible 
target for the area of MPIs could be the MT1-MMP which plays a critical role in cancer invasion. Interestingly, HNSCC is consistently related to MT1-MMP overexpression ${ }^{179-181}$ and was also one of the first human cancers associated with MT1-MMP expression. ${ }^{182}$

\section{The tumor microenvironment}

Rather than being malignant cells growing in isolation, cancer is a complex tissue where many different cell types (e.g., fibroblasts, endothelial cells, pericytes, and inflammatory cells) and ECM interact in a multipart ecosystem, called the tumor microenvironment. Even though Paget hypothesized of the seed and the soil already in $1889,{ }^{183}$ it is only recently accepted that cancer progression is a product from crosstalk between different cell types within the tumor and its surrounding tumor stroma. ${ }^{184-186}$ 


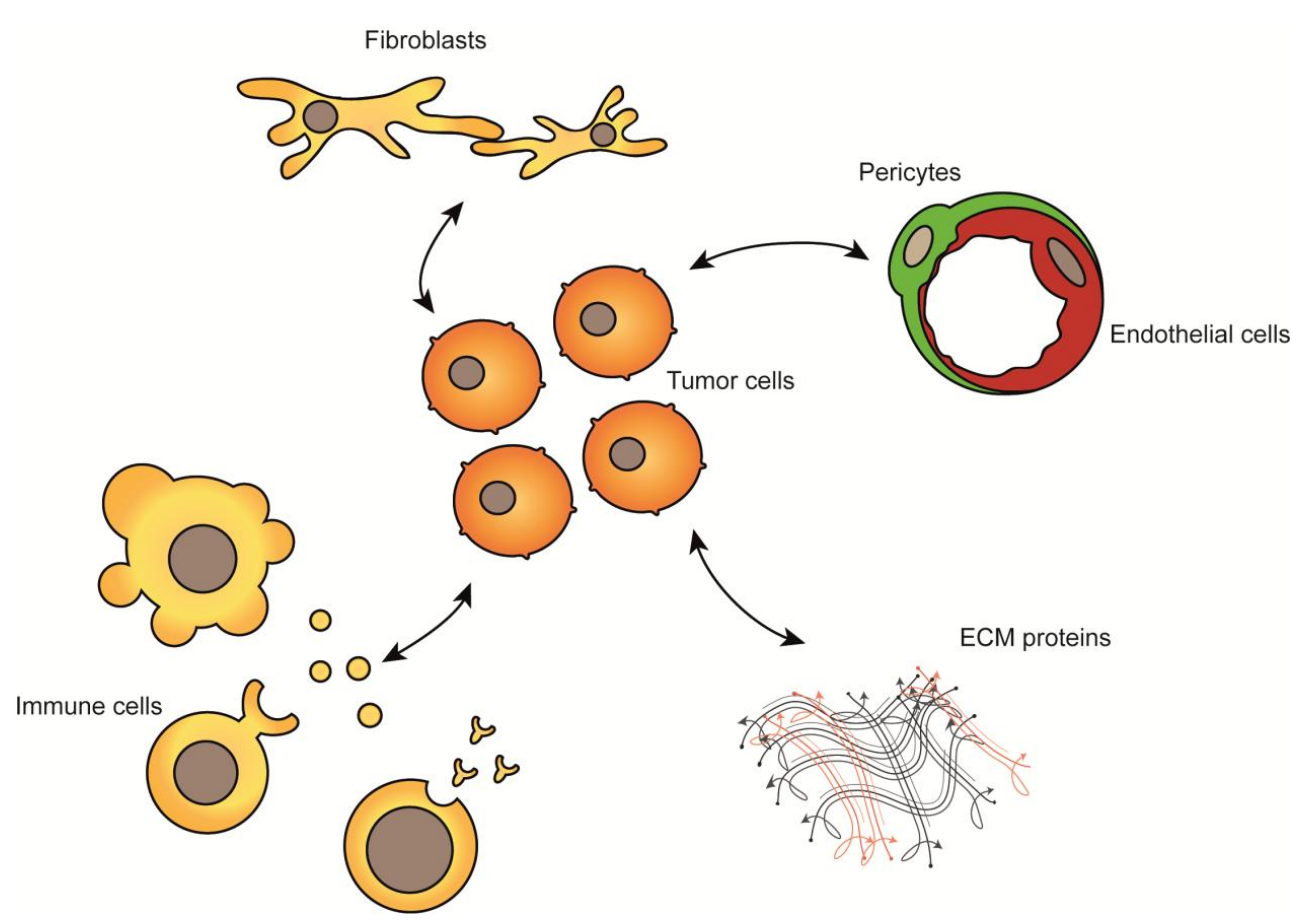

Figure 3. The tumor microenvironment consists of many different cells such as fibroblasts, endothelial cells, pericytes, and inflammatory cells, as well as extracellular matrix (ECM). All these cells have properties that, if deregulated, can contribute to cancer progression.

Already in pre-malignant dysplasia, fibroblasts, endothelial cells, pericytes, and immune cells are recruited to the stroma. There are many similarities between these tissue changes and the changes associated with wound repair, thus, cancer is commonly abridged as "a wound that never heals". ${ }^{187}$ The progression from dysplasia into invasive cancer involves disruption of the basement membrane barrier which enables direct contact between the tumor cells, stromal cells, and ECM. During this progression the normal stroma undergoes a transformation into a reactive tumor stroma, i.e., an abnormal stroma that supports tumor growth and metastasis. ${ }^{188-191}$ 
The most crucial element of the microenvironment is the cancer associated fibroblasts (CAFs) which are similar to fibroblasts involved in wound healing. CAFs derive from different subsets of cells including local fibroblasts, bone marrow-derived progenitor cells, and trans-differentiating epithelial cells. ${ }^{192}$ The term CAF is yet relatively poorly defined, and based mainly on the expression of certain markers such as $\alpha$-smooth-muscle actin, vimentin, collagen I, fibroblast specific protein-1 and platelet-derived growth factor receptor. ${ }^{193}$ Since CAFs may derive from many different cells, the expression of markers within CAFpopulations is heterogeneous and CAFs are also likely to display functional differences due to their origin.

CAFs modulate the tumor's fate by increasing tumor growth, ${ }^{188,194,195}$ EMT, ${ }^{184,186,196,197}$ the invasive potential, ${ }^{198,199}$ and metastasis ${ }^{196,200}$ by secretion of soluble factors or by modification of ECM components. ${ }^{201}$ In addition, the tumor stroma has also been suggested to modulate the drug sensitivity of cancer cells. Already in 1990 Teicher proposed that something other than the tumor cells' properties must affect their ability to resist cytotoxic drugs. ${ }^{202}$ In this study, mice bearing mammary tumors were over a 6-month period repeatedly treated with alkylating agents, resulting in resistance to the drug. However, this acquired drug resistance could only be seen in vivo and not in in vitro tumor cell culture, demonstrating that the surrounding tissue of the tumor, the tumor stroma, was influencing the tumor cells ability to resist cytotoxic drugs. Since then, numerous studies have shown that several different cell types within the tumor stroma, including CAFs, can influence the response to various anti-cancer treatments. $^{203-211}$

It is now clear that an abnormal stroma contribute to, or even is required for, tumor formation, progression, invasion, and resistance to anti-cancer treatments. One approach to slow or reverse this could be the design of targeted therapies 
aiming to normalize components of the stromal environment. Stromal cells, such as CAFs, are good therapeutic targets since these cells are more genetically stable than tumor cells and thus, are more likely to maintain sensitivity to drugs. ${ }^{212,213}$ In fact, there already exists drugs approved by the FDA that targets the tumor stroma. Bevacizumab, i.e., Avastin ${ }^{\circledR}$, a blocking monoclonal antibody against VEGF-signaling, has been shown to increase the overall survival for patients in a variety of cancers, including metastatic colon carcinoma, ${ }^{214}$ NSCLC ${ }^{215}$ metastatic renal cell carcinoma, ${ }^{216}$ and recurrent glioblastoma. ${ }^{217,218}$ On the contrary, Avastin ${ }^{\circledR}$ was accelerated approved for the use in metastatic breast cancer patients in 2008 but FDA revoked this approval in 2011 since two additional studies revealed no overall survival benefits. ${ }^{219,220}$ Furthermore, nonsteroidal anti-inflammatory drugs (NSAIDs), which inhibits inflammatory cells, has been shown to reduce the risk for gastrointestinal cancer. ${ }^{21-223}$ However, long-term use of NSAIDs may be problematic and result in dyspepsia, gastric bleeding, hypertension, renal failure, and cardiovascular diseases. ${ }^{224}$ One huge disappointment within the stromal targeted therapy area is, as mentioned before, the failure of MPIs. ${ }^{171}$ Because of this, the aim should be to find new drugs that target different aspects of the activated and abnormal stroma and combine them with cytotoxic therapies directed against the tumor cells. In that way the tumor will be treated as the heterogenic organ we now recognize it to be. 



\section{AIM OF THE THESIS}

The aim of this thesis was to uncover factors that affect treatment response in HNSCC. Finding predictive markers for treatment response would enable a more individualized treatment plan for HNSCC patients.

\section{Specific aims}

- By genome-wide microarray analysis and bioinformatics processing identify a transcriptional profile for cisplatin resistance as well as identify key regulators which have impact on cisplatin treatment response.

- Investigate the functional importance of the EGFR ligands EGF, AR, and EPR in relation to proliferation and cetuximab sensitivity.

- Study how CAFs affect cetuximab treatment response in HNSCC cells.

- Investigate the crosstalk between CAFs and tumor cells that may underlie cetuximab resistance.

- Investigate gene expression differences between tumor cells co-cultured with their patient-matched CAFs and tumor cells cultured alone. 



\section{MATERIAL AND METHODS}

\section{Cell lines from Turku University}

The HNSCC cell lines used in papers I and III were provided by Professor Reidar Grenman at Turku University, Finland. In paper I three cell lines were chosen for microarray analyses according to their sensitivity to cisplatin. A panel of 25 cell lines was used to evaluate the results. In paper III two larynx and two tongue cancer cell lines, all with an intermediate sensitivity for cetuximab, were selected. All cell lines were cultured in Dulbecco's Modified Eagle's Medium (DMEM) supplemented with glutamine, penicillin, streptomycin, and fetal bovine serum (FBS) and used in passages 20-35.

\section{Cell lines from Linköping University}

Tumor biopsies have been collected from HNSCC patients at the ENT (ear, nose, and throat) department at Linköping University Hospital from January 2004 and on (approved by the ethical committee at Linköping University Hospital, Dnr 03-537) and from this material 25 HNSCC cell lines have been established as previously described. ${ }^{225}$ Cell lines were cultured in Keratinocyteserum free medium (SFM) supplemented with penicillin, streptomycin, and 10\% FBS and used in passages 10-25. Cells were screened periodically for mycoplasma contamination using DAPI staining and/or the ATCC Universal Mycoplasma Detection Kit.

Linköping HNSCC cell lines were used in papers II and IV. In paper II, the cell lines were selected according to their sensitivity to cetuximab, as well as the 
location, histological grading, and TNM-status of the tumors from which they originate. In paper IV, five cell lines, to which patient-matched CAF-cultures were available, were used. These cell lines all originated either from tumors of the tongue or larynx.

\section{Establishment of Linköping CAF-cultures}

CAF cultures were established from the same tumor explants as the HNSCC cell lines and separated from the tumor cells by differential trypsinization. CAFs were cultured in DMEM supplemented with glutamine, penicillin, streptomycin, and 5\% FBS (paper III) or Keratinocyte-SFM supplemented with penicillin, streptomycin, and 10\% FBS (paper IV). Fibroblast origin was verified by positive immunofluorescent staining for vimentin and negative staining for cytokeratin. $^{203}$

Seven different CAF cultures originating from tumors of the tongue, larynx, tonsil, gingiva, and buccal mucosa were used in study III. In paper IV, CAF cultures originating from five tumors, from which HNSCC cell lines were established, were used. For all experiments, CAFs were used at passages 2-6.

\section{Assessment of intrinsic cisplatin- and cetuximab sensitivity}

The intrinsic cisplatin sensitivity (ICS) of 39 Turku HNSCC cell lines have previously been determined by a clonogenic assay. ${ }^{221}$ Cells were seeded in sixwell plates and cisplatin was added to the cultures. Cells were cultured for another nine days before fixation in $4 \%$ paraformaldehyde (PFA), staining with Giemsa, and counting of colonies containing 32 cells or more. 
For assessment of treatment sensitivity of the cell lines established in Linköping, the cells were seeded in 12-well plates and exposed to cisplatin or cetuximab. ${ }^{225}$ After incubation for nine days, the cells were fixed in 4\% PFA and stained with $0.04 \%$ crystal violet in $1 \%$ ethanol. The stained colonies were solubilized in $1 \%$ SDS (sodium dodecyl sulfate) and optical density was measured using a Victor plate reader (Perkin-Elmer) at $550 \mathrm{~nm}$.

\section{Co-culture systems and collection of conditioned medium}

Three different co-culture systems were used in papers III and IV in order to investigate if CAFs had any effects on the tumor cell growth, the response to cetuximab, or the tumor cell gene expressions. A transwell system (Figure 4A), using filter inserts with $0.4 \mu \mathrm{m}$ pore size, through which cells are unable to pass, were used in experiments where cell-cell contact was not allowed. Tumor cells were first plated at the bottom of the well and were allowed to attach before CAFs were seeded on the filters, resulting in an approximate 1:1 ratio of CAFs to tumor cells. In this system, tumor cells and CAFs can only communicate through soluble factors. In the second system, in which cell-cell contact was allowed (Figure 4B), tumor cells and CAFs were co-cultured together in cell culture flasks. Tumor cell and CAF numbers were adjusted so that an approximate ratio of 3:1 was achieved by the end of co-culture. In the third system, CAF conditioned medium (CM) was added to tumor cell mono-cultures (Figure $4 \mathrm{C}$ ). The amount of $\mathrm{CM}$ in the wells represented $25 \%$ of the total volume. CAF CM was collected from confluent cultures $72 \mathrm{~h}$ after medium change. 

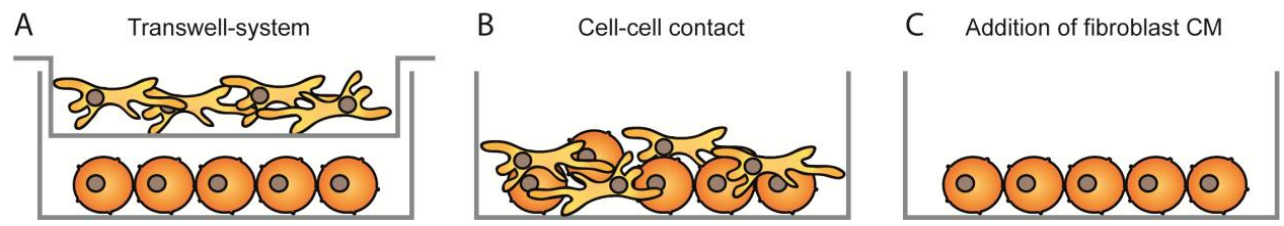

Figure 4. Three different co-culture systems were used in this thesis. (A) A transwell system, using filter inserts with $0.4 \mu \mathrm{m}$ pore size polycarbonate membranes, which do not allow cellcell contact between tumor cells and cancer associated fibroblasts (CAFs). (B) A co-culture of tumor cells and CAFs in cell culture flasks which allows for cell-cell contact. (C) Addition of fibroblast conditioned medium (CM), which contains CAF secreted soluble factors, to tumor cell mono-cultures.

\section{Migration assay}

In paper IV, a transwell migration assay was used in order to investigate the influence of CAFs on tumor cell migration. The tumor cells were stained with CellTracker ${ }^{\mathrm{TM}}$ Green and seeded with (allowing cell-cell contact) or without CAFs into filter inserts with an $8 \mu \mathrm{m}$ pore size. The tumor cells were allowed to migrate for $48 \mathrm{~h}$ before they were collected and the fluorescence was measured at $485 / 535 \mathrm{~nm}$ with a Victor plate reader. A standard curve with cell numbers ranging from 5000 to 50000 was used to determine the number of migrating tumor cells.

\section{Microarray and bioinformatics}

In paper I microarray was used to study gene expression differences between one cisplatin sensitive cell line and two cisplatin resistant cell lines. The chip which was used in this paper (Affymetrix Human Genome U133 Plus 2.0) analyses the expression of 38500 genes. By comparing the differentially expressed transcripts among the two resistant cell lines with the sensitive cell line, one can easier separate the characteristics of cisplatin resistance and study 
the pathways. However, the amount of data retrieved from this analysis requires appropriate statistical and bioinformatics processing in order to obtain manageable results. The gene ontology tree machine (GOTM) analyses a set of genes and detects transcripts present in enriched groups based on their assigned gene ontology. Such analysis sheds light on the processes that are involved in cisplatin resistance and additionally facilitates the exclusion of transcripts of limited importance. Ingenuity pathway analysis (IPA) provides molecular networks from a reference gene list. This enables the identification of key regulators, i.e., molecules that interact with several other factors in a network, which in this case are involved in cisplatin resistance.

Microarray was also used in paper IV in order to compare the gene expression of tumor cells co-cultured with their patient-matched CAF and tumor cells cultured alone. The chip used in this paper (Affymetrix Gene Chip Human Exon 1.0 ST) analyses the expression on exon-level (i.e., enables to distinguish between different isoforms of a gene) on a whole-genome scale. In this paper $\mathrm{R} /$ Bioconductor packages were used as tool for the analysis and comprehension of the microarray results. IPA was used to investigate the association with important biological functions which may be related to the genes found to be differentially expressed in tumor cells co-cultured with CAFs when compared to tumor cells cultured alone.

\section{Quantitative real-time PCR}

Quantitative real-time PCR (qPCR) analysis was used to determine the relative messenger RNA (mRNA) expression. The values were calculated by the comparative $\mathrm{Ct}$ method $^{226}$ which presents the data as a fold-difference in expression level relative to a calibrator sample. Glyceraldehyde-3-phosphate dehydrogenase was amplified as an internal standard. 
In paper I qPCR was used in order to verify the microarray results and to examine the expression of the genes of interest in a larger panel of cell lines. qPCR was also used in paper IV for verification of microarray results and to study the gene expression differences between tumor cells in co-cultures allowing cell-cell contact and co-cultures which do not. The qPCR method was used in papers II and III to verify gene knockdown by RNA interference. Moreover, in paper III the expression of a number of genes primarily involved in EMT, EGFR signaling, and treatment resistance were studied by multi qPCR.

\section{Western blot}

The semi-quantitative method western blot was used to examine the relative protein abundances in cell lysates. In paper III this technique was applied to analyze the expression of EGFR downstream effectors upon co-culture with $\mathrm{CAF}$ and cetuximab treatment. Unequal loading was adjusted by correlation of the protein bands to $\beta$-actin.

\section{ELISA}

ELISA is a quantitative method that can be used to determine the expression of a specific protein in a sample. In paper II, ELISA was used to verify gene silencing of AR, EGF, and EPR in HNSCC cells. In paper III, this method was also used to verify downregulation of MMP-1 and hepatocyte growth factor (HGF) expression in CAF CM, and to study the amounts of these proteins in $\mathrm{CM}$ from co-cultures as well as tumor cell and CAF mono-cultures. The amount of the detected proteins was determined using a standard curve constructed by plotting the mean relative fluorescence units (for MMP-1) or the mean absorbance (for AR, EGF, EPR, and HGF) for each standard against the concentration. 


\section{RNA interference}

RNA interference is a method that specifically downregulates the expression of a particular gene. Short interfering RNAs (siRNAs) are short ( $<25$ nucleotides) double-stranded duplexes which in the cells are unwound into two singlestranded RNAs (ssRNAs). One of the strands is degraded and the other is incorporated into the so-called RNA-inducing silencing complex. This complex targets and cleaves the mRNA that is complementary to the incorporated ssRNA and thus, gene silencing is achieved since the translation of targeted genes is interrupted.

In paper II siRNA-mediated knockdown of the EGFR ligands EGF, AR, and EPR was performed to study their effects on cetuximab treatment response and cell proliferation. siRNA transfection was also used in paper III to attain gene silencing of HGF and MMP-1 in order to clarify their role in CAF-induced cetuximab resistance.

\section{Magnetic activated cell sorting}

The magnetic activated cell sorting (MACS) method allows for separation of various cell populations based on their expression of surface antigens. The technique is based on magnetism and antibodies directed against a particular antigen. Cells expressing the specific antigen will be separated from cells which do not express the antigen. The separation of a subset of cells can be achieved either through positive selection, i.e., selection of the cells expressing the antigen of interest, or by negative selection, i.e., the antibody used is directed against surface antigens which are present on cells that are not of interest.

MACS was used in paper IV to separate tumor cells from CAFs after co-culture in culture flasks. Tumor cells were positively selected using magnetic beads 
conjugated to antibodies directed against the epithelial marker EpCAM. These tumor cells were thereafter used in the microarray analysis.

\section{Flow cytometry and fluorescence activated cell sorting}

Flow cytometry is a method which can be employed for a variety of purposes, including cell counting, cell sorting, and protein detection. This technique is based on cells passing one by one through a laser beam where reflected and scattered light are measured. The reflected light gives information of the cell volume and the scattered light is correlated to shape of the nucleus, the amount and type of cytoplasmic granules, or the membrane roughness. One can also use fluorophore-conjugated antibodies that bind to a specific protein and thus estimate the amount of that protein. Fluorescence activated cell sorting (FACS) is one type of flow cytometry, which sorts cells using the information gained by the flow cytometry.

In paper IV, the FACSAria flow cytometer was used in order to sort tumor cells expressing enhanced green fluorescent protein (EGFP). The EGFP expressing tumor cells were later co-cultured or not with CAFs with the purpose to investigate cell growth and cetuximab response. The number of EGFP expressing cells in co-cultures was determined by the flow cytometer, FACSCalibur.

\section{Statistical methods}

In paper $\mathrm{I}$, the non-parametric Mann-Whitney $U$ test was used to analyze possible association between MMP-7 and -13 expression and ICS. 
In paper II, one-way ANOVA followed by t-tests with the Bonferroni adjustment was used to calculate differences between the groups.

In paper III, one-way ANOVA followed by Bonferroni or Dunnett's post-hoc tests was used to calculate differences between the groups.

In paper IV, Student's t-test was used to calculate differences between the groups.

For all statistical analyses performed in this thesis, p-values $\leq 0.05$ were considered significant. 



\section{RESULTS AND DISCUSSION}

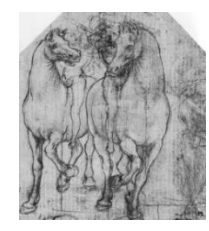

\section{Results paper I}

Cisplatin is the most common and effective chemotherapeutic drug used for treatment of locally advanced HNSCC but clinical resistance to the drug is a major problem. Since $70-80 \%$ of the patients that receive cisplatin do not respond to the treatment, but still experience the severe side-effects, we here aimed to find predictive markers of intrinsic cisplatin resistance(i.e., present at the time of initial treatment).

In order to identify differences between cisplatin sensitive and cisplatin resistant cells, we performed an unsupervised study using microarray analysis and 781 transcripts were found to be differentially expressed in both of the resistant cell lines compared to the sensitive cell line. To understand and manage the large amount of data retrieved from the microarray analysis the GOTM and IPA tools were used for enrichment of gene ontologies and network analysis, respectively. By applying the GOTM tool to the gene list 11 functional categories (Table 2, paper I) were found to be enriched in the two resistant cell lines versus the sensitive one. Using IPA seven molecular networks containing 20 key regulator genes, i.e., genes interacting with at least three altered transcripts were identified (Table 3, paper I). The top scoring network from the IPA analysis, in which the key regulators FN1, MMP-7, MMP-13, THBS1, and TIMP3 were identified, is shown in Figure 5. 


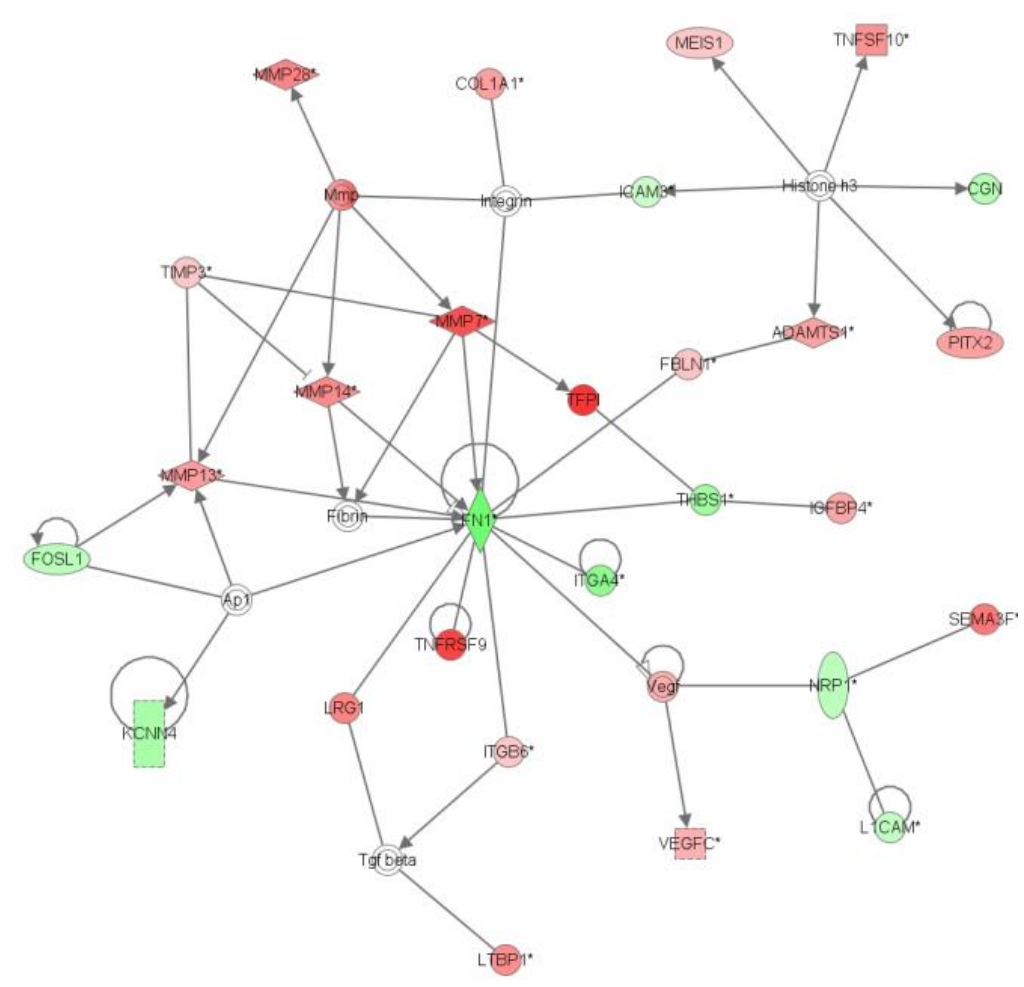

Figure 5. The top scoring network from the IPA analysis in which FN1, MMP-7, MMP-13, THBS1, and TIMP3 were identified as key regulators of cisplatin resistance.

Of the 20 identified key regulators, six (APOE, CTNNB1, MMP-7, MMP-13, THBS1, and TIMP3) were found to be differentially expressed in the resistant cell lines compared to the sensitive. These were further selected for qPCR analysis, and for all genes except for TIMP3, the microarray result was verified. In order to further evaluate the importance of these key regulators APOE, CTNNB1, MMP-7, MMP-13, and THBS1 were selected for analysis of mRNA expression in a panel $25 \mathrm{HNSCC}$ cell lines with known ICS. The cell lines were divided into two groups corresponding to high or low expression of the gene of interest, and the ICS was thereafter compared between the groups. It was demonstrated that a high MMP-7 expression significantly correlated to cisplatin 
resistance $(\mathrm{p}=0.0013$, Figure $2 \mathrm{~A}$, paper I) and that the MMP-13 expression showed a strong tendency to be associated with the cisplatin treatment response $(\mathrm{p}=0.058$, Figure $2 \mathrm{~B}$, paper I).

\section{Discussion paper I}

Since resistance to cisplatin is a major problem in the clinic the search for predictive markers is crucial. In order to find markers predictive for cisplatin resistance one need to understand the molecular mechanisms that underlie chemoresistance. Therefore, in this study, we aimed to reveal the intrinsic dissimilarities between HNSCC cells that are resistant and cells that are sensitive to cisplatin.

The mechanisms underlying intrinsic cisplatin resistance may differ from those responsible for acquired resistance (i.e., adapted through repeated exposure to the drug) which is common during treatment. The acquired resistance is frequently due to decreased platinum accumulation, elevated drug inactivation by metallothionine and glutathione, and enhanced DNA repair activity ${ }^{90}$ while the failure of apoptotic pathways ${ }^{92,227}$ such as the apoptotic signaling via Fas/Fas ligand (FasL) are commonly responsible for the intrinsic resistance. ${ }^{93}$

Both MMP-7 and MMP-13 belong to the family of matrix metalloproteinases which includes at least 23 different members. Because of their influence on tumor progression and invasion MMPs are potential targets for anti-cancer treatments. ${ }^{171}$ Indeed, several MPIs have been developed through the years but the results from the clinical trials have been very disappointing. However, because of the design of these trials the knowledge about MMPs in carcinogenesis has improved; it is nowadays believed that MMPs play an important role in early cancer development as well as in the late stage. ${ }^{172,173}$ 
MMP-13 belongs to the group of collagenases within the MMP family and their main action is to cleave interstitial collagens I, II, and III. ${ }^{170}$ Studies have shown that MMP-13 frequently is expressed by primary HNSCC but rarely in normal tissue. $^{228}$ This is well in line with the fact that MMP-13 was found to be upregulated during tumor growth and invasion, situations where rapid matrix turnover is needed. In addition, a high MMP-13 expression is associated with tumor aggressiveness and shorter overall survival in HNSCC and may have a prognostic value. $^{229}$

Matrilysins, which includes MMP-7, is a group of MMPs that lack the hemopexin domain which is common to other MMPs. ${ }^{170,230}$ MMP-7 is one of the few MMPs which is synthesized and expressed in tumor cells themselves. MMP-7 is overexpressed in a majority of different cancer types, including HNSCC $^{231}$ and overexpression has also been shown to be associated with a shorter overall survival in this disease. MMP-7 is a very potent protease which cleaves many ECM components including elastin, type IV collagen, fibronectin, vitronectin, aggrecan, and proteoglycans. ${ }^{170,230}$ MMP-7 also plays an important role in the shedding of cell-surface molecules including tumor necrosis factor- $\alpha$, HB-EGF, E-cadherin, $\beta 4$-integrin, and the Fas death receptor ${ }^{232}$ and FasL. ${ }^{233}$ The shedding of E-cadherin is responsible for the increased migratory and invasive capacity of tumor cells, whereas the shedding of Fas and FasL by MMP-7 results in interrupted apoptosis and possibly resistance to cisplatin as the Fas/FasL pathway is known to contribute to cisplatin-induced cell death. ${ }^{230}$

Furthermore, MMP-7 expression has been found to correlate with EGFR activation. ${ }^{234}$ MMP-7 is also known to cleave HB-EGF resulting in cellular proliferation. ${ }^{230}$ Thus, an enhanced signaling through the EGFR may also contribute to MMP-7 associated cisplatin resistance. 
This study proposes a role for MMP-7 in the evasion of apoptosis during cisplatin treatment and suggests that MMP-7 may be a predictive marker for cisplatin resistance in HNSCC. Since MMPs, including MMP-7, nowadays are believed to be important in early cancer development and that MMP-7 expression selects for cells with reduced sensitivity to cisplatin, ${ }^{235}$ the development of selective MMP-7 inhibitors, given at an early stage in combination with cisplatin, might render cells more sensitive to cisplatin. 


\section{Results paper II}

Targeted therapy is a promising field in cancer management and such therapies are usually directed against growth factor receptors, such as EGFR, and their downstream signaling. The monoclonal EGFR antibody cetuximab has been approved for the treatment of locally advanced HNSCC but unfortunately only approximately $20 \%$ of the patients receiving this expensive treatment show disease stabilization and prolonged survival. Studies aiming at finding biomarkers that could predict the cetuximab treatment outcome in HNSCC patients are needed since there are no such markers available to date. In order to find biomarkers predictive of cetuximab response an increased knowledge about the EGFR signaling network is required. Therefore, in this study, we aimed to investigate the functional importance of the EGFR activating ligands EGF, AR, and EPR in relation to proliferation and cetuximab sensitivity in three tongue cancer cell lines; LK0412, LK0824, and LK0902.

The influence of EGF, AR, and EPR on tumor cell proliferation and cetuximab response was evaluated by the addition of recombinant human (rh) proteins or by siRNA-mediated downregulation of the endogenous ligand production.

The proliferative effect exerted by rhEGF differed among the three cell lines; an anti-proliferative effect was observed in the LK0412 and LK0824 cell lines, whereas an increase in the proliferative rate was seen in LK0902 (Figure 1A, paper II). A similar pattern was observed upon addition of rhEPR (Figure 1C, paper II) while rhAR did not exert any significant effect on cell growth in any of the three cell lines (Figure 1B, paper II). On the contrary, downregulation of endogenous AR caused reductions in tumor cell growth in all cell lines (Figure 2B, paper II). Also upon depletion of EGF a pronounced inhibition of proliferation was seen in all cell lines (Figure 2A, paper II). 
One of the main findings in this study was that all three cell lines displayed increased cetuximab resistance upon the addition of rhEGF (Figure 3A, paper II). In contrast, only LK0824 showed increased resistance after stimulation with rhAR (Figure 3B, paper II) and rhEPR (Figure 3C, paper II). Interestingly, this cell line was the only one that showed an increased sensitivity to cetuximab after silencing of EGF (Figure 4A, paper II). Furthermore, the siRNA-mediated downregulation of AR sensitized LK0412 to cetuximab treatment while an increase in resistance was seen in LK0902 (Figure 4B, paper II). LK0824 was unaffected by the depletion of endogenous AR.

\section{Discussion paper II}

The tyrosine kinase cell surface receptor EGFR is overexpressed in approximately $30 \%$ of all human epithelial tumors ${ }^{143}$ and in almost all HNSCC. ${ }^{144}$ Since EGFR commonly is overexpressed and a high expression is associated with shorter overall survival and loco-regional failure, therapies aiming to prevent EGFR signaling have been developed. The monoclonal antibody cetuximab was approved for the treatment of locally advanced HNSCC by the FDA in 2006. Despite promising results in clinical trials the response rate in patients with HNSCC is only about $20 \% .{ }^{107,110,116,117}$ In contrast to colorectal cancer, where KRAS mutation status is a well established predictive marker for cetuximab resistance, ${ }^{118}$ predictive markers for cetuximab treatment outcome are lacking in HNSCC. HNSCC is one of the most heterogeneous cancer types with tumors from many different locations (e.g., oral cavity, pharynx, larynx, and paranasal sinuses) and this might explain the difficulties in finding predictive biomarkers. Therefore, in this study, we selected a relatively homogenous cell line panel with three cell lines derived from mobile tongue and with similar TNM-status and histological grade (Table 1, paper II). Regardless of this the 
results were diverse and highlight the problem with tumor heterogeneity and the complexity of the EGFR signaling network in cancer.

In this study, it was demonstrated that EGF and AR are important for tongue cancer cell proliferation and that EGF is a potential predictive biomarker of poor cetuximab response. Indeed, many studies have suggested EGFR ligands to regulate response to EGFR-targeted therapies. ${ }^{156-163,225,236}$ For example, it has been suggested that high expression of AR and EPR predict good response to cetuximab in KRAS wild-type colorectal cancers ${ }^{158,161,162}$ and in concordance with this, the development of acquired cetuximab resistance has been linked to the downregulation of AR and EPR. ${ }^{156}$ Here, depletion of endogenous AR inhibited the tumor cell growth in all cell lines (Figure 2B, paper II) suggesting that downregulation of AR makes tumor cells less aggressive. However, the impact of AR depletion on the cetuximab response differed between the three cell lines (Figure 4B, paper II). While LK0902 became more resistant to cetuximab, which is in agreement with the above mentioned studies, LK0412 became more sensitive. Nevertheless, it has recently been shown that a high AR expression level correlates with poor response to cetuximab-docetaxel treatment in HNSCC patients. ${ }^{159}$

EGF was found to induce resistance to cetuximab in all cell lines (Figure 3A, paper II). Moreover, depletion of endogenous EGF resulted in a significant increase in cetuximab sensitivity in the LK0824 cell line, and the same tendency was also seen in LK0412 (Figure 4A, paper II). This suggests that EGF is a potential predictive marker for cetuximab resistance in tongue cancer. Surprisingly, the mRNA expression of EGF was low and we were not able to detect any EGF in culture media from the cell lines tested. However, our results suggest that the low amount of EGF is sufficient to induce cetuximab resistance. Autocrine growth factor production of EGF might compete with blocking 
antibodies for binding to the EGFR and thus reduce their effectiveness. ${ }^{237}$ The greater impact of EGF on the cetuximab treatment response could be explained by the fact that EGF has a much higher affinity to EGFR than AR and EPR. ${ }^{238,239}$ Interestingly, stromal cells were shown to have a higher expression of EGF than epithelial cells. ${ }^{240}$ Speculatively, stromal cells such as CAFs might be the main EGF producers within HNSCC tumors and may hence induce cetuximab resistance in a paracrine fashion.

Taken together, this study showed that EGF and AR are critical components of the EGFR signaling network that is required to maintain the full proliferative potential in tongue cancer cell lines and that EGF is a potential predictive biomarker of poor cetuximab response and a possible treatment target. 


\section{Results paper III}

A tumor is not a homogenous mass consisting only of tumor cells but rather a complex network with tumor cells, fibroblasts, endothelial cells, pericytes, inflammatory cells, and ECM that interact in a multipart ecosystem. CAFs, which are one of the major components of the tumor microenvironment, are known to stimulate tumor growth and induce resistance to various anti-cancer treatments. For that reason we investigated the possible influence of CAFs on the cetuximab response in HNSCC cell lines.

During co-culture of four tumor cell lines with seven different CAFs in a transwell system (Figure 4A), a partial or full protection against the effect of cetuximab on the tumor cells was observed (Figure 1, paper III). In the UTSCC-9 cell line cetuximab treatment even stimulated cell growth in the presence of CAFs (Figure 1A, paper III). However, this stimulation was not seen for UTSCC-24A (Figure 1B, paper III), UT-SCC-19A (Figure 1C, paper III), or UTSCC-76A (Figure 1D, paper III). Interestingly, the stimulation of UT-SCC-9 cell growth during cetuximab treatment was not accompanied by CAF-induced changes in the tumor cell proliferation rate in the absence of cetuximab (Figure 2A, paper III). Conversely, the other three cell lines, in which CAFs showed a more modest protection from cetuximab, were all growth stimulated in the presence of CAFs (Figures 2B-D, paper III).

To find out whether the increased resistance to cetuximab was due to CAFs specifically interfering with the interaction between cetuximab and EGFR or if they counteracted the action of EGFR-targeting therapies in general, the cells were treated with the EGFR-selective tyrosine kinase inhibitor gefitinib. Similar results were found for gefitinib as for cetuximab (Figure 3, paper III) suggesting that CAFs affect EGFR inhibition in general. 
When medium conditioned by CAFs was added to the cells (Figure 4C) a similar protection from cetuximab treatment was seen as during co-culture with CAFs (Figures 4A and B, paper III). These results suggest that treatment resistance is mediated by CAF-derived soluble factors. In addition, by sizefractionation of the CM it was shown that soluble factors larger than $50 \mathrm{kDa}$ are likely to be responsible for the protective effect (Figure 4D, paper III).

The cetuximab resistance observed in co-cultured tumor cells could not be explained by changes in the expression or phosphorylation status of EGFR within tumor cells (Figures 5A and B, paper III) or by secretion of HGF from CAFs (Figure 6, paper III). In an attempt to identify the soluble factors responsible for the increased resistance to cetuximab in tumor cells, we performed a mass spectrometry analysis in which CM was compared with complete growth medium. However, we were unable to get any conclusive results from this analysis. The lack of results can be explained by the presence of high-abundance serum proteins in the CM, which may have obscured any low-abundance factors present. Unfortunately CAFs could not be cultured in SFM without showing reduced viability. Therefore we instead performed a multi qPCR in order to study expression differences between mono- and co-cultured tumor cells in a panel of genes. From this analysis we observed an elevated expression of MMP-1 in co-cultured tumor cells, and this was later found to be true also for co-cultured CAFs (Figure 7A, paper III). The CAF-induced cetuximab resistance was significantly decreased when using an MMP inhibitor; (Figure 7C, paper III) however, downregulation of MMP-1 in CAFs or in tumor cells did not increase the sensitivity to cetuximab (Figures 7D and E, paper III). This may indicate that several CAF-regulated MMPs cooperate in the induction of resistance. 


\section{Discussion paper III}

Cancer research has for a long time been focused mainly on the cancer cell and its molecular changes; however, it is now accepted that the tumor microenvironment contributes to cancer progression and may influence the response of different cancer types to various anti-cancer treatments. CAFs, which are the most abundant cell type of the tumor stroma, have been shown to modulate the drug sensitivity in cancers of epithelial origin. Indeed, CAFs were demonstrated to induce resistance to tamoxifen in breast cancer, ${ }^{205,208}$ paclitaxel and gefitinib in NSCLC, ${ }^{206,207}$ and to gemcitabine and radiotherapy in pancreatic adenocarcinoma. ${ }^{241}$ Here, we show for the first time that CAFs also induce resistance to cetuximab. However, the soluble factors responsible for this increased resistance to cetuximab in HNSCC are yet to be identified. Interestingly, CAF-secreted HGF has been suggested to be the causing factor for resistance to gefitinib ${ }^{206}$ and to an irreversible EGFR tyrosine kinase inhibitor ${ }^{242}$ in NSCLC. Clinical trials combining c-Met inhibitors with EGFR tyrosine kinase inhibitors are ongoing. ${ }^{243,244}$ In our hands, addition of rhHGF to tumor cell monocultures confirmed that HGF can induce treatment resistance (Figure 6B, paper III). Still, even though endogenous HGF was depleted in CAFcultures the $\mathrm{CM}$ collected from these cultures still protected the tumor cells from cetuximab (Figure 6C, paper III). This excluded HGF to be the soluble factor contributing to the CAF-induced cetuximab resistance in HNSCC cells. However, CAFs may derive from many different subsets of cells and are likely to display functional differences depending on their origin ${ }^{193}$ thus, different CAF-secreted factors may be important for treatment sensitivity in diverse cancer types.

We performed a multi qPCR to study differences in gene expression between mono- and co-cultured tumor cells in order to identify the soluble factors 
responsible for the increased resistance to cetuximab. From this analysis tumor cells co-cultured with CAFs were found to have an upregulated expression of MMP-1 (Figure 7A, paper III). In addition, co-cultured CAFs also had a higher expression of MMP-1 than CAF mono-cultures which propose that factors originating from both CAFs and tumor cells are responsible for the resistance to cetuximab. Interestingly, an inhibitor of MMP-1 reduced the protective effect of CAF-CM (Figure 7C, paper III) but the CAF-induced cetuximab resistance was not diminished by downregulation of endogenous MMP-1 in either CAFs or tumor cells (Figures 7D and E, paper III). The MMP-1 inhibitor used could to some extent also block MMP-2, -3, -7, and -13, indicating that a MMP other than MMP-1 may mediate the resistance, or that several CAF-regulated MMPs cooperate in the induction of drug resistance. Hence, in a family of approximately 23 members it is unlikely that only one MMP could have significant impact on cetuximab treatment resistance.

Since our results suggest that factors associated with both CAFs and tumor cells influence the outcome of EGFR-targeted therapy this highlights the importance that anti-cancer therapies should target both stromal cells and tumor cells. However, it is very difficult to find the molecules that transmit signals between tumor cells and stromal cells since the nature of these molecules is largely obscure and this complicates the development of therapies targeting the tumor stroma. High-throughput screening of tumor cells and CAFs may be a helpful tool in understanding the complex molecular crosstalk between stromal cells and tumor cells and ultimately in the discovery of factors affecting treatment resistance in tumor cells.

In this study we identify a novel CAF-dependent modulation of cetuximab sensitivity and suggest that inhibiting MMPs may improve the effects of EGFRtargeted therapy. 


\section{Results paper IV}

In paper III we showed that the increased resistance to cetuximab was due to secreted factors from CAFs but unfortunately we were unable to identify the specific factor/factors responsible for this. Therefore, in this study we performed a microarray analysis in order to compare gene expression differences between tumor cells co-cultured with their patient-matched CAFs and tumor cells cultured alone, in an attempt to identify the causative soluble factors.

Upon co-culture with CAFs, a thousand genes or more were deregulated in each individual tumor cell line tested. More importantly, 58 protein coding genes $(\mathrm{Q}<0.05)$ were found to be differentially expressed in all five co-cultured tumor cells. Of these 58 genes, nine were upregulated by $\geq 1.5$-fold (Table II, paper IV) while 35 were found to be downregulated by $\leq 0.67$-fold (Table III, paper IV). Interestingly, many of the deregulated genes have earlier been associated with EMT. Five of the differentially expressed protein coding genes (COL1A2, GREM1, MMP-7, POSTN, and VIM) were selected for verification by qPCR and for COL1A2, GREM1, POSTN, and MMP-7 a change in expression upon co-culture with CAFs was verified in all five cell lines (Figures 3A-C, E, paper IV). The decreased expression of VIM could be verified in four out of the five cell lines (Figure 3D, paper IV). Furthermore, these changes in expression levels were all found to be dependent on cell-cell contact (Figure 4, paper IV) since they could only be detected in co-cultures allowing cell-cell contact (Figure 4B) and not in the transwell system (Figure 4A).

The influence of CAFs on tumor cell proliferation, cetuximab response, and migration was also investigated and gave varying results (Figure 5, paper IV) e.g., a slight protective effect from cetuximab was observed in one of the cell 
lines upon co-culture with CAFs while the opposite was seen in another (Figure 5B, paper IV).

\section{Discussion paper IV}

As nowadays accepted, a tumor is a heterogeneous and structurally complex tissue which does not consist of only malignant cells but also of fibroblasts, endothelial cells, pericytes, and inflammatory cells, which together with the ECM constitute the tumor stroma. CAFs are the major cellular component of the tumor stroma and they have been shown to stimulate tumor growth, ${ }^{188,194,195}$ EMT, ${ }^{184,186,196,197}$ invasion, ${ }^{198,199}$ and metastasis ${ }^{196,200}$ and to influence treatment response, by secretion of soluble factors. ${ }^{203-211}$ The detection of the soluble factors that are responsible for the influence on treatment response could lead to the development of new treatment strategies. However, the crosstalk between cancer cells and CAFs are still not completely understood and the nature of the soluble factors is largely obscure.

In this study, we show that CAFs affect the gene expression in tumor cells and that this is dependent on cell-cell contact. This might be due to both juxtacrine and paracrine signaling in co-cultures allowing cell-cell contact. In addition, the local concentration of soluble factors might be higher when the two cell types are in close contact which may be required in order to induce gene expression changes in the tumor cells.

In paper III we showed that CAFs induced resistance to cetuximab in HNSCC cells, however; in this study the results differed among the three cell lines i.e., one cell line became more resistant to cetuximab whereas one showed higher sensitivity (Figure 5B, paper IV). The discrepancy between the results might be due to the difference in the individual ability of tumor cells to respond to CAFsignals, as seen in both paper III (Figure 2) and paper IV (Figure 5). As HNSCC 
cells are highly heterogeneous they will probably respond differently toward CAF-signals. Therefore, targeting one aspect in the complicated crosstalk between tumor cells and CAFs will most likely not work. Hence, an increased understanding of the crosstalk between cancer cells and CAFs is of critical importance in order to find different treatment targets within the tumor stroma which can be used in combinations with standard treatments.

Taken together, we here show that CAFs induce multiple gene expression changes in their patient-matched tumor cells, and that 58 of them are common among all five tumor cell lines investigated. A number of these deregulated genes have been implicated in the EMT process. Furthermore, our data shows that tumor cells and CAFs need to be in close contact for at least some of these changes to occur. 


\section{CONCLUCIONS}

The following conclusions can be drawn from the results presented in this thesis:

- High expression of MMP-7 is significantly correlated to intrinsic cisplatin resistance.

- High expression of MMP-13 shows a strong tendency to affect cisplatin treatment outcome.

- EGF is a potential predictive biomarker of poor cetuximab response and a possible treatment target.

- CAFs induce resistance to cetuximab treatment through the secretion of soluble factors.

- MMPs are partly responsible for the observed CAF-induced resistance to cetuximab.

- CAFs induce multiple gene expression changes in tumor cells, some of which are associated to EMT.

- The CAF-induced gene expression changes of COL1A2, GREM1, MMP7, POSTN, and VIM is dependent on cell-cell contact.

- The tumor cell response to CAF-signals varies between individuals. 



\section{FUTURE PERSPECTIVES}

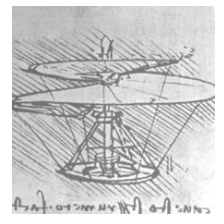

HNSCC is one of the most distressing human cancer types and two-thirds of the patients have advanced disease with lymph node metastasis at diagnosis. Since patients with HNSCC tends to be diagnosed at a late stage, which usually means a poorer prognosis than for early stage tumors, efforts to achieve earlier diagnoses should be made. Late diagnosis is probably due to lack of knowledge about the disease and ignorance of symptoms, which delay the visit to a physician. Since most people go to the dentist more often than to the doctor, information on HNSCC from their dentist or dental hygienist may make people visit a physician at an earlier time point.

HPV-positive HNSCCs have grown strong in Sweden in recent years. A preventive act for this would be to expand the HPV-vaccination program to also include boys, especially since it has been shown that men have a higher rate of HPV-positive tumors. Today the HPV-vaccination aims to reduce the incidence of HPV-induced cervix cancer in women.

Besides preventive actions, it is very important to find improvements for the treatment regime that can be used in the clinic. The field of oncology has now entered the era of personalized medicine where treatments can be individually selected for each patient. Clinically useful predictive biomarkers of treatment outcome have been found for colorectal and breast cancers but is still lacking for HNSCC. This is likely due to the high heterogeneity within this group of tumors, which makes them act and respond very differently to treatments. Indeed, we have in the studies in this thesis seen that the response of HNSCC 
tumor cells to CAF-signals varies greatly. In addition, even though we chose a more homogeneous panel of cell lines in one of our studies, i.e., tongue cancer cell lines with similar TNM-stage and histological grading, they still displayed very different responses to stimuli with EGFR ligands. In the future, the search for predictive markers of treatment response in HNSCC should aim to divide this group of tumors even further, not only depending on location of the tumor. Smokers/non-smokers (or other tobacco products), HPV-positive/HPV-negative, males/females, histological grades, and TNM-stages are examples of further groupings. However, it is necessary to collaborate with other clinics, as this will otherwise result in too small patient groups. We have started collaborations with the ENT clinics in Helsinki, Turku, and Stockholm, which enables us to verify our results obtained in in vitro studies in a larger group of patients subdivided according to tumor location, smoking habits, and HPV-status etcetera.

Finally, it would be very interesting to further investigate the functional importance of the deregulated genes found in paper IV, in relation to tumor cell proliferation, migration, and response to cetuximab. 


\section{ACKNOWLEDGEMENTS}

A thesis is not written by itself and is definitely not a result of the efforts of a single individual. Thus, I would like to express my deepest gratitude to the following colleagues and friends:

To Karin Roberg, my main supervisor. I want to give my deepest thanks to you, who made it all possible. You believed in me and guided me through these years and for that I am very grateful! Your commitment, experience, and ideas helped the project move forward even through the most frustrating moments such as cell culture studies that failed and so on... You have taught me an immense amount of science in our field of research and how to work independently. We share the same interest in horses, although you are as dedicated to dressage as I to show jumping, our love for horses unite us! I will forever be grateful for these years!

To Ann-Charlotte Johansson, my co-supervisor. What would I have done without you Lotta!? Your unconditional support and care for my work and me is more than I could ever have asked for. With you, I have been able to share my problems, both scientific and personal. Your corrections of my English writing are by far the most thorough I have ever had... but I have learned a lot and appreciate your help greatly! Thank you for everything!

To Charlotta Dabrosin. Thank you for being my co-supervisor and for teaching me about laboratory animals. 
To all past and present members of the Öron group. Fredrik Jerhammar, my lab-big brother! It has been so fun to work in the same group as you! You have taught me a lot about the complex world of bioinformatics for which I am forever grateful. You have also tried to teach me some other things, for example that junior PhD-students must provide the senior with coffee and that Peking is the best football team. I remain skeptical... Lovisa Farnebo for always being happy, friendly, helpful, and smashing! I appreciate all your fantastic skills, both professional and personal! Adam Jedlinski, my friend, which always is there when I need help, whether it is about support with presentations or prescriptions for heavy cough syrup! :) However, I still believe that motorbikes are more dangerous than horses... Linnéa LaFleur, you were like a fresh breath of air when you joined our group. You are a talented researcher and I wish you the best of luck in your new scientific adventure! Camilla Janefjord and Linda Vainikka, thank you for all your technical support which was invaluable for my work! Katarina Tiefenböck, Stella Mellissaridou, and Natasa Matic, I am so happy that you have joined our group but most of all that you all have become my friends!

To my co-authors; Rebecca Ceder, Roland Grafström, Reidar Grénman, Maja Bradic Lindh, Eva Munch-Wikland, Arne Östman, Matti Kankainen, Jan-Ingvar Jönsson, and Outi Monni. Each of you is like a piece of a puzzle, ever so important for the complete research picture.

Lena Thunell, you were my supervisor during my bachelor and master thesis and the one who introduced me to scientific research. Thank you!

My other colleagues at Patologen, plan 9: Jakob Domert, I want to thank you for all your help with the figures in my thesis and for becoming a really good friend of mine! Lotta Agholme, always having an answer to every question, whatever it is about, but most of all for your help with my Vera! 
Hanna Appelqvist, I have always been able to ask you about PhD-related things and for that I am forever in debt to you! Karin Öllinger and Katarina Kågedahl, even though I do not belong to your research groups, you where always there to help me! Sangeeta Nath, Amit Laskar, Petra Wäster, Aida Vahdat Shariatpanahi, Andrea Armstrong, Livia Civitelli, Emelie Severinsson, and Bengt-Arne Fredriksson, for enjoyable and sometimes educational coffee-breaks!

To Ida Eriksson and Linnea Sandin. Hours of laughter, tears and discussions on both work-related topics and of course issues of more private nature, (-) you are now more than my colleagues, you are my friends! I am truly grateful that both of you are my toast madams at the dissertation party!

To my stable friends, past and present, at Stall Stora Sjögestad, no one mentioned, no one forgotten. We have different goals in life, but we all share the love of horses and all fantastic moments in the stable together with you gives me great pleasure and new energy to resolve research problems!

To Olivia Friberg. Thank you for taking such good care of my beloved Kevin and that you love him just as much as I do. You are the best!

To my stunning friends, Erika Söderberg, Jeanette Bergdahl, Sara Jonson Anne-Li Sundefors, Linda Lätth, Nina Hedlund, and Helena Fristedt. Such crazy things we have done over the years and such fun we have had! I will not reveal anything here, because not all our escapades have a place in an academic thesis... Never kiss and tell! :) Nevertheless, I am so happy and fortunate to have you as friends and I love how we always care so much for each other!

To Ulrika Englund and Linda Fryland. We found each other the first week at the university and ever since we have been the best of friends! We have laughed, cried, studied, partied and traveled together, sometimes all at once! $\odot$ Having 
you as travel companions sometimes ends up in unexpected experiences and small catastrophes but we have always been able to laugh it off! Some of my best and happiest trips have been with you!

To my sweet Stina Hallinder. You are one of my oldest friends and the sister I never had! I love our evenings when we sit in cozy clothes, drink wine and watch an awful reality show on TV, on which we of course commented loudly... Great evenings so to say, could it just be us who think that way!? :- I am so happy to have you in my life!

To my in-law family, Monika, Håkan, Magnus, and Mattias Schultz. Thank you for all your support, pep-talks, help with renovations and other matters and not least, for making me feel like a family member!

I must of course mention my four-legged darlings; Kevin, Vera, and Alfons who mean the world to me and who always help me take my mind off things!

To my wonderful parents, Pia and Hans Ansell. How can I begin to describe what you mean to me?! You are without a doubt the best parents one can have, always supportive, helping, loving, smart and funny! I am grateful for your support in my life decisions; regardless if it is about my $\mathrm{PhD}$-path or my big and sometimes crazy interest in horses... : I love you!

To my Martin. There are no words to express what I feel for you! Every day I thank my lucky star that I met you, the most beautiful person there is. I admire every part of you and there is nothing you cannot handle. For example, not every man could have coped with a new girlfriend who came accompanied by a cat; two horses and a bunch of very inquisitive friends... () But you did and you do! Thank you for your endless help and patience during the making of this thesis! Till tidens ände... Jag älskar dig. 


\section{REFERENCES}

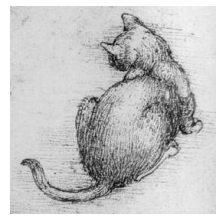

1. Argiris A, Karamouzis MV, Raben D, Ferris RL. Head and neck cancer. Lancet 2008;371:1695-709.

2. Leemans CR, Braakhuis BJM, Brakenhoff RH. The molecular biology of head and neck cancer. Nat Rev Cancer 2011;11:9-22.

3. Parkin DM, Bray F, Ferlay J, Pisani P. Global cancer statistics, 2002. CA Cancer J Clin 2005;55:74-108.

4. Henle G, Henle W. Epstein-Barr virus-specific IgA serum antibodies as an outstanding feature of nasopharyngeal carcinoma. Int J Cancer 1976;17:17.

5. Sousa H, Breda E, Santos AM, Catarino R, Pinto D, Medeiros R. Genetic Risk Markers for Nasopharyngeal Carcinoma in Portugal: Tumor Necrosis Factor Alpha -308G \&gt;A Polymorphism. DNA Cell Biol 2011;30:99103.

6. Ferlay J, Shin H-R, Bray F, Forman D, Mathers C, Parkin DM. Estimates of worldwide burden of cancer in 2008: GLOBOCAN 2008. Int J Cancer 2010;127:2893-917.

7. Freedman ND, Abnet CC, Leitzmann MF, Hollenbeck AR, Schatzkin A. Prospective investigation of the cigarette smoking-head and neck cancer association by sex. Cancer 2007;110:1593-601.

8. Suba Z. Common soil of smoking-associated and hormone-related cancers: estrogen deficiency. Oncol Rev 2010;4:73-87.

9. Suba Z. Gender-related hormonal risk factors for oral cancer. Pathol Oncol Res 2007;13:195-202.

10. Llewellyn C., Johnson N., Warnakulasuriya KAA. Risk factors for squamous cell carcinoma of the oral cavity in young people - a comprehensive literature review. Oral Oncol 2001;37:401-18. 
11. Annertz K, Anderson H, Biörklund A, et al. Incidence and survival of squamous cell carcinoma of the tongue in Scandinavia, with special reference to young adults. International Journal of Cancer 2002;101:95-9.

12. Llewellyn CD, Johnson NW, Warnakulasuriya K a. a. S. Risk factors for oral cancer in newly diagnosed patients aged 45 years and younger: a case-control study in Southern England. J Oral Pathol Med 2004;33:52532 .

13. Chen JK, Eisenberg E, Krutchkoff DJ, Katz RV. Changing trends in oral cancer in the United States, 1935 to 1985: a Connecticut study. J Oral Maxillofac Surg 1991;49:1152-8.

14. Carniol PJ, Fried MP. Head and neck carcinoma in patients under 40 years of age. Ann Otol Rhinol Laryngol 1982;91:152-5.

15. McGregor GI, Davis N, Robins RE. Squamous cell carcinoma of the tongue and lower oral cavity in patients under 40 years of age. Am J Surg 1983;146:88-92.

16. Tsukuda M, Ooishi K, Mochimatsu I, Sato H. Head and neck carcinomas in patients under the age of forty years. Jpn J Cancer Res 1993;84:748-52.

17. Cloos J, Spitz MR, Schantz SP, et al. Genetic Susceptibility to Head and Neck Squamous Cell Carcinoma. JNCI J Natl Cancer Inst 1996;88:530-5.

18. Gillison ML, Koch WM, Capone RB, et al. Evidence for a Causal Association Between Human Papillomavirus and a Subset of Head and Neck Cancers. JNCI J Natl Cancer Inst 2000;92:709-20.

19. D'Souza G, Kreimer AR, Viscidi R, et al. Case-Control Study of Human Papillomavirus and Oropharyngeal Cancer. N Engl J Med 2007;356:194456.

20. Decker J, Goldstein JC. Risk Factors in Head and Neck Cancer. N Engl J Med 1982;306:1151-5.

21. Lewin F, Norell SE, Johansson H, et al. Smoking tobacco, oral snuff, and alcohol in the etiology of squamous cell carcinoma of the head and neck: a population-based case-referent study in Sweden. Cancer 1998;82:1367-75.

22. MacKay J, Eriksen MP. The Tobacco Atlas. World Health Organization; 2002. 
23. Hecht SS. Tobacco carcinogens, their biomarkers and tobacco-induced cancer. Nat Rev Cancer 2003;3:733-44.

24. Pfeifer GP, Denissenko MF, Olivier M, Tretyakova N, Hecht SS, Hainaut $P$. Tobacco smoke carcinogens, DNA damage and p53 mutations in smoking-associated cancers. Oncogene 2002;21:7435-51.

25. Bannister JV, Halliwell B, O’Neill P. Free Radicals in Biological Medicine. Harwood Academic; 1985.

26. Pryor WA, Stone K, Zang L-Y, Bermúdez E. Fractionation of Aqueous Cigarette Tar Extracts: Fractions That Contain the Tar Radical Cause DNA Damage. Chem Res Toxicol 1998;11:441-8.

27. West KA, Brognard J, Clark AS, et al. Rapid Akt activation by nicotine and a tobacco carcinogen modulates the phenotype of normal human airway epithelial cells. J Clin Invest 2003;111:81-90.

28. Gartner $\mathrm{C}$, Hall $\mathrm{W}$. The potential role of snus in tobacco harm reduction. Addiction 2009;104:1586-7.

29. Vainio H, Weiderpass E. Smokeless tobacco: harm reduction or nicotine overload? Eur J Cancer Prev 2003;12:89-92.

30. Betel-quid and Areca-nut Chewing and Some Areca-nut-derived Nitrosamines. IARC; 2004.

31. Nair J, Ohshima H, Nair UJ, Bartsch H. Endogenous Formation of Nitrosamines and Oxidative DNA-Damaging Agents in Tobacco Users. Crit Rev Toxicol 1996;26:149-61.

32. Some Traditional Herbal Medicines, Some Mycotoxins, Naphthalene and Styrene. World Health Organization; 2002.

33. Carossa S, Pera P, Doglio $\mathrm{P}$, et al. Oral nitric oxide during plaque deposition. Eur J Clin Invest 2001;31:876-9.

34. Trivedy CR, Craig G, Warnakulasuriya S. The oral health consequences of chewing areca nut. Addict Biol 2002;7:115-25.

35. Reidy J, McHugh E, Stassen LFA. A review of the relationship between alcohol and oral cancer. Surgeon 2011;9:278-83.

36. Warnakulasuriya S. Causes of oral cancer - an appraisal of controversies. Br Dent J 2009;207:471-5. 
37. Ogden GR. Alcohol and oral cancer. Alcohol 2005;35:169-73.

38. Organization $\mathrm{WH}$, Humans IA for R on $\mathrm{CWG}$ on the $\mathrm{E}$ of $\mathrm{CR}$ to. IARC Monographs on the Evaluation of Carcinogenic Risks to Humans: Reevaluation of some organic chemicals, hydrazine and hydrogen peroxide. Vol.71. International Agency for Research on Cancer; 1999.

39. Figuero Ruiz E, Carretero Peláez MÁ, Cerero Lapiedra R, Esparza Gómez G, Moreno López LA. Effects of the consumption of alcohol in the oral cavity: Relationship with oral cancer. Medicina Oral 2004;9:14-23.

40. Jones AS. Oral cancer. J. P. Shah, N. W. Johnson and J. G. Batsakis (eds). $220 \times 290$ mm. Pp. 496. Illustrated. 2003. Martin Dunitz: London. Br J Surg 2003;90:1309-1309.

41. Blot WJ, McLaughlin JK, Winn DM, et al. Smoking and Drinking in Relation to Oral and Pharyngeal Cancer. Cancer Res 1988;48:3282-7.

42. Day GL, Blot WJ, Austin DF, et al. Racial Differences in Risk of Oral and Pharyngeal Cancer: Alcohol, Tobacco, and Other Determinants. JNCI J Natl Cancer Inst 1993;85:465-73.

43. Howie N, Trigkas T, Cruchley A, Wertz P, Squier C, Williams D. Shortterm exposure to alcohol increases the permeability of human oral mucosa. Oral Dis 2001;7:349-54.

44. Homann N, Jousimies-Somer H, Jokelainen K, Heine R, Salaspuro M. High acetaldehyde levels in saliva after ethanol consumption: methodological aspects and pathogenetic implications. Carcinogenesis 1997;18:1739-43.

45. Salaspuro MP. Acetaldehyde, Microbes, and Cancer of the Digestive Tract. Crit Rev Clin Lab Sci 2003;40:183.

46. ELMORE JG, HORWITZ RI. Oral cancer and mouthwash use: Evaluation of the epidemiologic evidence. Otolaryng Head Neck 1995; 113:253-61.

47. Vecchia CL. Mouthwash and oral cancer risk: An update. Oral Oncol 2009;45:198-200.

48. Stewart BW, Kleihues P, International Agency for Research on Cancer, World Health Organization. World cancer report. IARC;2003. 
49. Llewellyn CD, Linklater K, Bell J, Johnson NW, Warnakulasuriya S. An analysis of risk factors for oral cancer in young people: a case-control study. Oral Oncol 2004;40:304-13.

50. Lucenteforte E, Garavello W, Bosetti C, La Vecchia C. Dietary factors and oral and pharyngeal cancer risk. Oral Oncol 2009;45:461-7.

51. Levi F, Pasche C, La Vecchia C, Lucchini F, Franceschi S, Monnier P. Food groups and risk of oral and pharyngeal cancer. Int J Cancer 1998;77:705-9.

52. Hennekens CH. Micronutrients and Cancer Prevention. N Engl J Med 1986;315:1288-9.

53. Machlin LJ, Bendich A. Free radical tissue damage: protective role of antioxidant nutrients. FASEB J 1987;1:441-5.

54. Negri E, Franceschi S, Bosetti C, et al. Selected micronutrients and oral and pharyngeal cancer. Int J Cancer 2000;86:122-7.

55. Takezaki T, Hirose K, Inoue M, et al. Tobacco, alcohol and dietary factors associated with the risk of oral cancer among Japanese. Jpn J Cancer Res 1996;87:555-62.

56. Chow CK, Thacker RR, Changchit $\mathrm{C}$, et al. Lower levels of vitamin $\mathrm{C}$ and carotenes in plasma of cigarette smokers. J Am Coll Nutr 1986;5:305-12.

57. Enwonwu CO, Meeks VI. Bionutrition and oral cancer in humans. Crit Rev Oral Biol Med 1995;6:5-17.

58. Ramaswamy G, Rao VR, Kumaraswamy SV, Anantha N. Serum vitamins' status in oral leucoplakias--a preliminary study. Eur J Cancer, B, Oral Oncol 1996;32B:120-2.

59. Smith IM, Mithani SK, Mydlarz WK, Chang SS, Califano JA. Inactivation of the Tumor Suppressor Genes Causing the Hereditary Syndromes Predisposing to Head and Neck Cancer via Promoter Hypermethylation in Sporadic Head and Neck Cancers. ORL J Otorhinolaryngol Relat Spec 2010;72:44-50.

60. Handley TPB, McCaul JA, Ogden GR. Dyskeratosis congenita. Oral Oncol 2006;42:331-6. 
61. Tai J, Yang M, Ni X, et al. Genetic polymorphisms in cytochrome P450 genes are associated with an increased risk of squamous cell carcinoma of the larynx and hypopharynx in a Chinese population. Cancer Genet Cytogenet 2010;196:76-82.

62. Tanimoto K, Hayashi S, Yoshiga K, Ichikawa T. Polymorphisms of the CYP1A1 and GSTM1 gene involved in oral squamous cell carcinoma in association with a cigarette dose. Oral Oncol 1999;35:191-6.

63. Zhuo W, Wang Y, Zhuo X, et al. CYP1A1 and GSTM1 Polymorphisms and Oral Cancer Risk: Association Studies Via Evidence-Based MetaAnalyses. Cancer Invest 2009;27:86-95.

64. Marur S, D'Souza G, Westra WH, Forastiere AA. HPV-associated head and neck cancer: a virus-related cancer epidemic. Lancet Oncol 2010;11:781-9.

65. Hammarstedt $>$ Lalle, Dahlstrand H, Lindquist D, et al. The incidence of tonsillar cancer in Sweden is increasing. Acta Oto-laryngologica 2007;127:988-92.

66. Kreimer AR, Clifford GM, Boyle P, Franceschi S. Human Papillomavirus Types in Head and Neck Squamous Cell Carcinomas Worldwide: A Systematic Review. Cancer Epidemiol Biomarkers Prev 2005;14:467-75.

67. Näsman A, Attner P, Hammarstedt L, et al. Incidence of human papillomavirus (HPV) positive tonsillar carcinoma in Stockholm, Sweden: an epidemic of viral-induced carcinoma? Int J Cancer 2009;125:362-6.

68. Attner P, Du J, Näsman A, et al. Human papillomavirus and survival in patients with base of tongue cancer. Int J Cancer 2011;128:2892-7.

69. Bui TC, Markham CM, Ross MW, Mullen PD. Examining the Association between Oral Health and Oral HPV Infection. Cancer Prev Res (Phila) 2013;6:917-24.

70. Münger K, Howley PM. Human papillomavirus immortalization and transformation functions. Virus Res 2002;89:213-28.

71. Werness BA, Levine AJ, Howley PM. Association of human papillomavirus types 16 and 18 E6 proteins with $\mathrm{p} 53$. Science 1990;248:76-9. 
72. Dyson N, Howley PM, Münger K, Harlow E. The human papilloma virus$16 \mathrm{E} 7$ oncoprotein is able to bind to the retinoblastoma gene product. Science 1989;243:934-7.

73. Shah JP, Lydiatt W. Treatment of cancer of the head and neck. CA Cancer J Clin 1995;45:352-68.

74. Shah JP, Gil Z. Current concepts in management of oral cancer - Surgery. Oral Oncol 2009;45:394-401.

75. Haddad RI, Shin DM. Recent Advances in Head and Neck Cancer. N Engl J Med 2008;359:1143-54.

76. Shah JP. Surgical Approaches to the Oral Cavity Primary and Neck. Int J Radiat Oncol 2007;69:S15-S18.

77. Vokes EE, Weichselbaum RR, Lippman SM, Hong WK. Head and Neck Cancer. N Engl J Med 1993;328:184-94.

78. Cooper JS, Farnan NC, Asbell SO, et al. Recursive partitioning analysis of 2105 patients treated in Radiation Therapy Oncology Group studies of head and neck cancer. Cancer 1996;77:1905-11.

79. Ang KK. Altered fractionation trials in head and neck cancer. Semin Radiat Oncol 1998;8:230-6.

80. Bourhis J, Overgaard J, Audry H, et al. Hyperfractionated or accelerated radiotherapy in head and neck cancer: a meta-analysis. Lancet 2;368:84354.

81. Fu KK, Pajak TF, Trotti A, et al. A radiation therapy oncology group (RTOG) phase III randomized study to compare hyperfractionation and two variants of accelerated fractionation to standard fractionation radiotherapy for head and neck squamous cell carcinomas: first report of RTOG 9003. Int J Radiat 2000;48:7-16.

82. Silva P, Homer J j., Slevin $\mathrm{N} \mathrm{j}$., et al. Clinical and biological factors affecting response to radiotherapy in patients with head and neck cancer: a review. Clin Otolaryngol 2007;32:337-45.

83. Chen DJ, Nirodi CS. The Epidermal Growth Factor Receptor: A Role in Repair of Radiation-Induced DNA Damage. Clin Cancer Res 2007;13:6555-60. 
84. Cohen EEW, Lingen MW, Vokes EE. The Expanding Role of Systemic Therapy in Head and Neck Cancer. JCO 2004;22:1743-52.

85. Rosenberg B, Van Camp L, Krigas T. Inhibition of cell division in escherichia coli by electrolysis products from a platinum electrode. Nature 1965;205:698-9.

86. Kelland L. The resurgence of platinum-based cancer chemotherapy. Nat Rev Cancer 2007;7:573-84.

87. Peyrone M. Ueber die Einwirkung des Ammoniaks auf Platinchlorür. Justus Liebigs Annalen der Chemie 1844;51:1-29.

88. Rosenberg B, VanCamp L, Trosko JE, Mansour VH. Platinum compounds: a new class of potent antitumour agents. Nature $1969 ; 222: 385-6$.

89. Jacobs C, Lyman G, Velez-García E, et al. A phase III randomized study comparing cisplatin and fluorouracil as single agents and in combination for advanced squamous cell carcinoma of the head and neck. J Clin Oncol 1992;10:257-63.

90. Rabik CA, Dolan ME. Molecular mechanisms of resistance and toxicity associated with platinating agents. Cancer Treat Rev 2007;33:9-23.

91. Alderden RA, Hall MD, Hambley TW. The Discovery and Development of Cisplatin. J Chem Educ 2006;83:728.

92. Niedner H, Christen R, Lin X, Kondo A, Howell SB. Identification of Genes That Mediate Sensitivity to Cisplatin. Mol Pharmacol 2001;60:1153-60.

93. Mansouri A, Ridgway LD, Korapati AL, et al. Sustained Activation of JNK/p38 MAPK Pathways in Response to Cisplatin Leads to Fas Ligand Induction and Cell Death in Ovarian Carcinoma Cells. J Biol Chem 2003;278:19245-56.

94. Boulikas T, Vougiouka M. Cisplatin and platinum drugs at the molecular level (Review). Oncol Rep 2003;10:1663-82.

95. Bernier J, Domenge C, Ozsahin M, et al. Postoperative Irradiation with or without Concomitant Chemotherapy for Locally Advanced Head and Neck Cancer. N Engl J Med 2004;350:1945-52. 
96. Brizel DM, Albers ME, Fisher SR, et al. Hyperfractionated Irradiation with or without Concurrent Chemotherapy for Locally Advanced Head and Neck Cancer. N Engl J Med 1998;338:1798-804.

97. Cooper JS, Pajak TF, Forastiere AA, et al. Postoperative Concurrent Radiotherapy and Chemotherapy for High-Risk Squamous-Cell Carcinoma of the Head and Neck. N Engl J Med 2004;350:1937-44.

98. Jeremic B, Shibamoto Y, Milicic B, et al. Hyperfractionated Radiation Therapy With or Without Concurrent Low-Dose Daily Cisplatin in Locally Advanced Squamous Cell Carcinoma of the Head and Neck: A Prospective Randomized Trial. JCO 2000;18:1458-64.

99. Huguenin P, Beer KT, Allal A, et al. Concomitant Cisplatin Significantly Improves Locoregional Control in Advanced Head and Neck Cancers Treated With Hyperfractionated Radiotherapy. JCO 2004;22:4665-73.

100. Forastiere AA, Goepfert H, Maor M, et al. Concurrent Chemotherapy and Radiotherapy for Organ Preservation in Advanced Laryngeal Cancer. N Engl J Med 2003;349:2091-8.

101. Wendt TG, Grabenbauer GG, Rödel CM, et al. Simultaneous radiochemotherapy versus radiotherapy alone in advanced head and neck cancer: a randomized multicenter study. J Clin Oncol 1998;16:1318-24.

102. Pignon J-P, le Maître A, Bourhis J. Meta-Analyses of Chemotherapy in Head and Neck Cancer (MACH-NC): An Update. Int J Radiat 2007;69:S112-S114.

103. Pignon J-P, le Maître A, Maillard E, Bourhis J, MACH-NC Collaborative Group. Meta-analysis of chemotherapy in head and neck cancer (MACHNC): an update on 93 randomised trials and 17,346 patients. Radiother Oncol 2009;92:4-14.

104. Pignon JP, Bourhis J, Domenge C, Designé L. Chemotherapy added to locoregional treatment for head and neck squamous-cell carcinoma: three meta-analyses of updated individual data. MACH-NC Collaborative Group. Meta-Analysis of Chemotherapy on Head and Neck Cancer. Lancet 2000;355:949-55.

105. Adelstein DJ, Li Y, Adams GL, et al. An Intergroup Phase III Comparison of Standard Radiation Therapy and Two Schedules of Concurrent Chemoradiotherapy in Patients With Unresectable Squamous Cell Head and Neck Cancer. JCO 2003;21:92-8. 
106. Mehra R, Cohen RB, Burtness BA. The Role of Cetuximab for the Treatment of Squamous Cell Carcinoma of the Head and Neck. Clin Adv Hematol Oncol 2008;6:742-50.

107. Bonner JA, Harari PM, Giralt J, et al. Radiotherapy plus Cetuximab for Squamous-Cell Carcinoma of the Head and Neck. N Engl J Med 2006;354:567-78.

108. Bonner JA, Harari PM, Giralt J, et al. Radiotherapy plus cetuximab for locoregionally advanced head and neck cancer: 5-year survival data from a phase 3 randomised trial, and relation between cetuximab-induced rash and survival. Lancet Oncol 2010;11:21-8.

109. Vermorken JB, Mesia R, Rivera F, et al. Platinum-Based Chemotherapy plus Cetuximab in Head and Neck Cancer. N Engl J Med 2008;359:111627.

110. Shin DM, Donato NJ, Perez-Soler R, et al. Epidermal Growth Factor Receptor-targeted Therapy with C225 and Cisplatin in Patients with Head and Neck Cancer. Clin Cancer Res 2001;7:1204-13.

111. Bourhis J, Rivera F, Mesia R, et al. Phase I/II Study of Cetuximab in Combination With Cisplatin or Carboplatin and Fluorouracil in Patients With Recurrent or Metastatic Squamous Cell Carcinoma of the Head and Neck. JCO 2006;24:2866-72.

112. Burtness B, Goldwasser MA, Flood W, Mattar B, Forastiere AA. Phase III Randomized Trial of Cisplatin Plus Placebo Compared With Cisplatin Plus Cetuximab in Metastatic/Recurrent Head and Neck Cancer: An Eastern Cooperative Oncology Group Study. JCO 2005;23:8646-54.

113. Baselga J, Trigo JM, Bourhis J, et al. Phase II Multicenter Study of the Antiepidermal Growth Factor Receptor Monoclonal Antibody Cetuximab in Combination With Platinum-Based Chemotherapy in Patients With Platinum-Refractory Metastatic and/or Recurrent Squamous Cell Carcinoma of the Head and Neck. JCO 2005;23:5568-77.

114. Herbst RS, Arquette M, Shin DM, et al. Phase II Multicenter Study of the Epidermal Growth Factor Receptor Antibody Cetuximab and Cisplatin for Recurrent and Refractory Squamous Cell Carcinoma of the Head and Neck. JCO 2005;23:5578-87.

115. Vermorken JB, Trigo J, Hitt R, et al. Open-Label, Uncontrolled, Multicenter Phase II Study to Evaluate the Efficacy and Toxicity of 
Cetuximab As a Single Agent in Patients With Recurrent and/or Metastatic Squamous Cell Carcinoma of the Head and Neck Who Failed to Respond to Platinum-Based Therapy. JCO 2007;25:2171-7.

116. Baselga J, Pfister D, Cooper MR, et al. Phase I Studies of Anti-Epidermal Growth Factor Receptor Chimeric Antibody C225 Alone and in Combination With Cisplatin. JCO 2000;18:904-904.

117. Robert F, Ezekiel MP, Spencer SA, et al. Phase I Study of Anti-Epidermal Growth Factor Receptor Antibody Cetuximab in Combination With Radiation Therapy in Patients With Advanced Head and Neck Cancer. JCO 2001;19:3234-43.

118. Lièvre A, Bachet J-B, Corre DL, et al. KRAS Mutation Status Is Predictive of Response to Cetuximab Therapy in Colorectal Cancer. Cancer Res 2006;66:3992-5.

119. Kiaris H, Spandidos DA, Jones AS, Vaughan ED, Field JK. Mutations, expression and genomic instability of the $\mathrm{H}$-ras proto-oncogene in squamous cell carcinomas of the head and neck. Br J Cancer 1995;72:1238.

120. Sato JD, Kawamoto T, Le AD, Mendelsohn J, Polikoff J, Sato GH. Biological effects in vitro of monoclonal antibodies to human epidermal growth factor receptors. Mol Biol Med 1983;1:511-29.

121. Li S, Schmitz KR, Jeffrey PD, Wiltzius JJW, Kussie P, Ferguson KM. Structural basis for inhibition of the epidermal growth factor receptor by cetuximab. Cancer Cell 2005;7:301-11.

122. Goldstein NI, Prewett M, Zuklys K, Rockwell P, Mendelsohn J. Biological efficacy of a chimeric antibody to the epidermal growth factor receptor in a human tumor xenograft model. Clin Cancer Res 1995;1:1311-8.

123. Kimura H, Sakai K, Arao T, Shimoyama T, Tamura T, Nishio K. Antibody-dependent cellular cytotoxicity of cetuximab against tumor cells with wild-type or mutant epidermal growth factor receptor. Cancer Sci 2007;98:1275-80.

124. Rogers SN. Quality of life for head and neck cancer patients - has treatment planning altered? Oral Oncol 2009;45:435-9.

125. McGuire WL. Steroid hormone receptors in breast cancer treatment strategy. Recent Prog Horm Res 1980;36:135-56. 
126. Bast RC, Ravdin P, Hayes DF, et al. 2000 Update of Recommendations for the Use of Tumor Markers in Breast and Colorectal Cancer: Clinical Practice Guidelines of the American Society of Clinical Oncology*. JCO 2001;19:1865-78.

127. Cobleigh MA, Vogel CL, Tripathy D, et al. Multinational Study of the Efficacy and Safety of Humanized Anti-HER2 Monoclonal Antibody in Women Who Have HER2-Overexpressing Metastatic Breast Cancer That Has Progressed After Chemotherapy for Metastatic Disease. JCO 1999;17:2639-2639.

128. Slamon DJ, Leyland-Jones B, Shak S, et al. Use of Chemotherapy plus a Monoclonal Antibody against HER2 for Metastatic Breast Cancer That Overexpresses HER2. N Engl J Med 2001;344:783-92.

129. Ullrich A, Schlessinger J. Signal transduction by receptors with tyrosine kinase activity. Cell 1990;61:203-12.

130. Licitra L, Störkel S, Kerr KM, et al. Predictive value of epidermal growth factor receptor expression for first-line chemotherapy plus cetuximab in patients with head and neck and colorectal cancer: Analysis of data from the EXTREME and CRYSTAL studies. Eur J Cancer 2013;49:1161-8.

131. Licitra L, Mesia R, Rivera F, et al. Evaluation of EGFR gene copy number as a predictive biomarker for the efficacy of cetuximab in combination with chemotherapy in the first-line treatment of recurrent and/or metastatic squamous cell carcinoma of the head and neck: EXTREME study. Ann Oncol 2011;22:1078-87.

132. Pirker R, Pereira JR, von Pawel J, et al. EGFR expression as a predictor of survival for first-line chemotherapy plus cetuximab in patients with advanced non-small-cell lung cancer: analysis of data from the phase 3 FLEX study. Lancet Oncol 2012;13:33-42.

133. Dassonville O, Formento JL, Francoual M, et al. Expression of epidermal growth factor receptor and survival in upper aerodigestive tract cancer. $\mathrm{J}$ Clin Oncol 1993;11:1873-8.

134. Rubin Grandis J, Melhem MF, Barnes EL, Tweardy DJ. Quantitative immunohistochemical analysis of transforming growth factor-alpha and epidermal growth factor receptor in patients with squamous cell carcinoma of the head and neck. Cancer 1996;78:1284-92. 
135. Wiest T, Schwarz E, Enders C, Flechtenmacher C, Bosch FX. Involvement of intact HPV16 E6/E7 gene expression in head and neck cancers with unaltered p53 status and perturbed pRb cell cycle control. Oncogene 2002;21:1510-7.

136. Namazie A, Alavi S, Olopade OI, et al. Cyclin D1 Amplification and p16(MTS1/CDK4I) Deletion Correlate With Poor Prognosis in Head and Neck Tumors. Laryngoscope 2002;112:472-81.

137. Okami K, Reed AL, Cairns $\mathrm{P}$, et al. Cyclin D1 amplification is independent of p16 inactivation in head and neck squamous cell carcinoma. Oncogene 1999;18:3541-5.

138. Pyeon D, Newton MA, Lambert PF, et al. Fundamental Differences in Cell Cycle Deregulation in Human Papillomavirus-Positive and Human Papillomavirus-Negative Head/Neck and Cervical Cancers. Cancer Res 2007;67:4605-19.

139. Marsit CJ, Black CC, Posner MR, Kelsey KT. A Genotype-Phenotype Examination of Cyclin D1 on Risk and Outcome of Squamous Cell Carcinoma of the Head and Neck. Clin Cancer Res 2008;14:2371-7.

140. Fakhry C, Westra WH, Li S, et al. Improved Survival of Patients With Human Papillomavirus-Positive Head and Neck Squamous Cell Carcinoma in a Prospective Clinical Trial. JNCI J Natl Cancer Inst 2008;100:261-9.

141. Spanos WC NP. IMmune response during therapy with cisplatin or radiation for human papillomavirus-related head and neck cancer. Arch Otolaryngol Head Neck Surg 2009;135:1137-46.

142. Williams R, Lee DW, Elzey BD, Anderson ME, Hostager BS, Lee JH. Preclinical models of HPV + and HPV - HNSCC in mice: An immune clearance of HPV+ HNSCC. Head \& Neck 2009;31:911-8.

143. Kuan CT, Wikstrand CJ, Bigner DD. EGF mutant receptor vIII as a molecular target in cancer therapy. Endocr Relat Cancer 2001;8:83-96.

144. Argiris A, Eng C. Epidemiology, staging, and screening of head and neck cancer. Cancer Treat Res 2003;114:15-60.

145. Mendelsohn J, Baselga J. The EGF receptor family as targets for cancer therapy. Oncogene 2000;19:6550-65. 
146. Klapper LN, Glathe S, Vaisman N, et al. The ErbB-2/HER2 oncoprotein of human carcinomas may function solely as a shared coreceptor for multiple stroma-derived growth factors. Proc Natl Acad Sci USA 1999;96:49955000 .

147. Ono M, Kuwano M. Molecular mechanisms of epidermal growth factor receptor (EGFR) activation and response to gefitinib and other EGFRtargeting drugs. Clin Cancer Res 2006;12:7242-51.

148. Tzahar E, Waterman $\mathrm{H}$, Chen X, et al. A hierarchical network of interreceptor interactions determines signal transduction by Neu differentiation factor/neuregulin and epidermal growth factor. Mol Cell Biol 1996;16:5276-87.

149. Lenferink AE, Pinkas-Kramarski R, van de Poll ML, et al. Differential endocytic routing of homo- and hetero-dimeric ErbB tyrosine kinases confers signaling superiority to receptor heterodimers. EMBO J 1998;17:3385-97.

150. Yarden Y, Sliwkowski MX. Untangling the ErbB signalling network. Nat Rev Mol Cell Biol 2001;2:127-37.

151. Oda K, Matsuoka Y, Funahashi A, Kitano H. A comprehensive pathway map of epidermal growth factor receptor signaling. Mol Syst Biol 2005;1:2005.0010.

152. Harris RC, Chung E, Coffey RJ. EGF receptor ligands. Exp Cell Res 2003;284:2-13.

153. De Luca A, Gallo M, Aldinucci D, et al. Role of the EGFR ligand/receptor system in the secretion of angiogenic factors in mesenchymal stem cells. $\mathrm{J}$ Cellular Physiol 2011;226:2131-8.

154. Sok JC, Coppelli FM, Thomas SM, et al. Mutant epidermal growth factor receptor (EGFRvIII) contributes to head and neck cancer growth and resistance to EGFR targeting. Clin Cancer Res 2006;12:5064-73.

155. Wheeler DL, Huang S, Kruser TJ, et al. Mechanisms of acquired resistance to cetuximab: role of HER (ErbB) family members. Oncogene 2008;27:3944-56.

156. Oliveras-Ferraros C, Cufi S, Queralt B, et al. Cross-suppression of EGFR ligands amphiregulin and epiregulin and de-repression of FGFR3 
signalling contribute to cetuximab resistance in wild-type KRAS tumour cells. Br J Cancer 2012;106:1406-14.

157. Busser B, Sancey L, Josserand V, et al. Amphiregulin Promotes Resistance to Gefitinib in NonSmall Cell Lung Cancer Cells by Regulating Ku70 Acetylation. Mol Ther 2010;18:536-43.

158. Saridaki Z, Tzardi M, Papadaki C, et al. Impact of KRAS, BRAF, PIK3CA Mutations, PTEN, AREG, EREG Expression and Skin Rash in $\geq 2$ nd Line Cetuximab-Based Therapy of Colorectal Cancer Patients. PLoS One 2011;6:e15980.

159. Tinhofer I, Klinghammer K, Weichert W, et al. Expression of Amphiregulin and EGFRvIII Affect Outcome of Patients with Squamous Cell Carcinoma of the Head and Neck Receiving Cetuximab-Docetaxel Treatment. Clin Cancer Res 2011;17:5197-204.

160. Hatakeyama H, Cheng H, Wirth P, et al. Regulation of Heparin-Binding EGF-Like Growth Factor by miR-212 and Acquired Cetuximab-Resistance in Head and Neck Squamous Cell Carcinoma. PLoS One 2010;5:e12702.

161. Khambata-Ford S, Garrett CR, Meropol NJ, et al. Expression of Epiregulin and Amphiregulin and K-ras Mutation Status Predict Disease Control in Metastatic Colorectal Cancer Patients Treated With Cetuximab. JCO 2007;25:3230-7.

162. Jacobs B, Roock WD, Piessevaux H, et al. Amphiregulin and Epiregulin mRNA Expression in Primary Tumors Predicts Outcome in Metastatic Colorectal Cancer Treated With Cetuximab. JCO 2009;27:5068-74.

163. Yonesaka K, Zejnullahu K, Lindeman N, et al. Autocrine Production of Amphiregulin Predicts Sensitivity to Both Gefitinib and Cetuximab in EGFR Wild-type Cancers. Clin Cancer Res 2008;14:6963-73.

164. Li C, Iida M, Dunn EF, Ghia AJ, Wheeler DL. Nuclear EGFR Contributes to Acquired Resistance to Cetuximab. Oncogene 2009;28:3801-13.

165. Black PC, Brown GA, Inamoto T, et al. Sensitivity to epidermal growth factor receptor inhibitor requires E-cadherin expression in urothelial carcinoma cells. Clin Cancer Res 2008;14:1478-86.

166. Fuchs BC, Fujii T, Dorfman JD, et al. Epithelial-to-mesenchymal transition and integrin-linked kinase mediate sensitivity to epidermal 
growth factor receptor inhibition in human hepatoma cells. Cancer Res 2008;68:2391-9.

167. Basu D, Nguyen T-TK, Montone KT, et al. Evidence for mesenchymallike sub-populations within squamous cell carcinomas possessing chemoresistance and phenotypic plasticity. Oncogene 2010;29:4170-82.

168. Holz C, Niehr F, Boyko M, et al. Epithelial-mesenchymal-transition induced by EGFR activation interferes with cell migration and response to irradiation and cetuximab in head and neck cancer cells. Radiother Oncol 2011;101:158-64.

169. Rosenthal EL, Matrisian LM. Matrix metalloproteases in head and neck cancer. Head Neck 2006;28:639-48.

170. Visse R, Nagase H. Matrix Metalloproteinases and Tissue Inhibitors of Metalloproteinases Structure, Function, and Biochemistry. Circ Res 2003;92:827-39.

171. Coussens LM, Fingleton B, Matrisian LM. Matrix metalloproteinase inhibitors and cancer: trials and tribulations. Science 2002;295:2387-92.

172. Egeblad M, Werb Z. New functions for the matrix metalloproteinases in cancer progression. Nat Rev Cancer 2002;2:161-74.

173. Hojilla CV, Mohammed FF, Khokha R. Matrix metalloproteinases and their tissue inhibitors direct cell fate during cancer development. Br J Cancer 2003;89:1817-21.

174. Rosenthal EL, McCrory A, Talbert M, Carroll W, Magnuson JS, Peters GE. Expression of proteolytic enzymes in head and neck cancer-associated fibroblasts. Arch Otolaryngol Head Neck Surg 2004;130:943-7.

175. Shekhar MP, Werdell J, Santner SJ, Pauley RJ, Tait L. Breast stroma plays a dominant regulatory role in breast epithelial growth and differentiation: implications for tumor development and progression. Cancer Res 2001;61:1320-6.

176. Lara PN Jr, Stadler WM, Longmate J, et al. A randomized phase II trial of the matrix metalloproteinase inhibitor BMS-275291 in hormone-refractory prostate cancer patients with bone metastases. Clin Cancer Res 2006;12:1556-63. 
177. Bergers G, Javaherian K, Lo K-M, Folkman J, Hanahan D. Effects of Angiogenesis Inhibitors on Multistage Carcinogenesis in Mice. Science 1999;284:808-12.

178. Zucker S, Cao J. Selective matrix metalloproteinase (MMP) inhibitors in cancer therapy. Cancer Biol Ther 2009;8:2371-3.

179. Rosenthal EL, Hotary K, Bradford C, Weiss SJ. Role of membrane type 1matrix metalloproteinase and gelatinase $\mathrm{A}$ in head and neck squamous cell carcinoma invasion in vitro. Otolaryngol Head Neck Surg 1999;121:33743.

180. Imanishi Y, Fujii M, Tokumaru Y, et al. Clinical significance of expression of membrane type 1 matrix metalloproteinase and matrix metalloproteinase-2 in human head and neck squamous cell carcinoma. Hum Pathol 2000;31:895-904.

181. Yoshizaki T, Sato H, Maruyama Y, et al. Increased expression of membrane type 1-matrix metalloproteinase in head and neck carcinoma. Cancer 1997;79:139-44.

182. Okada A, Bellocq JP, Rouyer N, et al. Membrane-type matrix metalloproteinase (MT-MMP) gene is expressed in stromal cells of human colon, breast, and head and neck carcinomas. Proc Natl Acad Sci USA 1995;92:2730-4.

183. Paget $\mathrm{S}$. The distribution of secondary growths in cancer of the breast. 1889. Cancer Metastasis Rev 1989;8:98-101.

184. Hanahan D, Coussens LM. Accessories to the Crime: Functions of Cells Recruited to the Tumor Microenvironment. Cancer Cell 2012;21:309-22.

185. Hanahan D, Weinberg RA. Hallmarks of Cancer: The Next Generation. Cell 2011;144:646-74.

186. Kalluri R, Zeisberg M. Fibroblasts in cancer. Nat Rev Cancer 2006;6:392401.

187. Dvorak HF. Tumors: wounds that do not heal. Similarities between tumor stroma generation and wound healing. N Engl J Med 1986;315:1650-9.

188. Camps JL, Chang SM, Hsu TC, et al. Fibroblast-mediated acceleration of human epithelial tumor growth in vivo. PNAS 1990;87:75-9. 
189. Olumi AF, Grossfeld GD, Hayward SW, Carroll PR, Tlsty TD, Cunha GR. Carcinoma-associated Fibroblasts Direct Tumor Progression of Initiated Human Prostatic Epithelium. Cancer Res 1999;59:5002-11.

190. Karnoub AE, Dash AB, Vo AP, et al. Mesenchymal stem cells within tumour stroma promote breast cancer metastasis. Nature 2007;449:557-63.

191. Anderberg C, Li H, Fredriksson L, et al. Paracrine Signaling by PlateletDerived Growth Factor-CC Promotes Tumor Growth by Recruitment of Cancer-Associated Fibroblasts. Cancer Res 2009;69:369-78.

192. Anderberg C, Pietras K. On the origin of cancer-associated fibroblasts. Cell Cycle 2009;8:1461-5.

193. Sugimoto H, Mundel TM, Kieran MW, Kalluri R. Identification of fibroblast heterogeneity in the tumor microenvironment. Cancer Biol Ther 2006;5:1640-6.

194. Östman A, Augsten M. Cancer-associated fibroblasts and tumor growth bystanders turning into key players. Curr Opin Genet Dev 2009;19:67-73.

195. Orimo A, Gupta PB, Sgroi DC, et al. Stromal Fibroblasts Present in Invasive Human Breast Carcinomas Promote Tumor Growth and Angiogenesis through Elevated SDF-1/CXCL12 Secretion. Cell 2005;121:335-48.

196. Gout S, Huot J. Role of Cancer Microenvironment in Metastasis: Focus on Colon Cancer. Cancer Microenviron 2008;1:69-83.

197. Soon PSH, Kim E, Pon CK, et al. Breast cancer-associated fibroblasts induce epithelial-to-mesenchymal transition in breast cancer cells. Endocr Relat Cancer 2013;20:1-12.

198. De Wever O, Demetter P, Mareel M, Bracke M. Stromal myofibroblasts are drivers of invasive cancer growth. Int J Cancer 2008;123:2229-38.

199. Fabra A, Nakajima M, Bucana CD, Fidler IJ. Modulation of the invasive phenotype of human colon carcinoma cells by organ specific fibroblasts of nude mice. Differentiation 1992;52:101-10.

200. Picard O, Rolland Y, Poupon MF. Fibroblast-dependent Tumorigenicity of Cells in Nude Mice: Implication for Implantation of Metastases. Cancer Res 1986;46:3290-4. 
201. Micke P, tman A. Tumour-stroma interaction: cancer-associated fibroblasts as novel targets in anti-cancer therapy? Lung Cancer 2004;45, Supplement 2:S163-S175.

202. Teicher BA, Herman TS, Holden SA, et al. Tumor resistance to alkylating agents conferred by mechanisms operative only in vivo. Science 1990;247:1457-61.

203. Johansson A-C, Ansell A, Jerhammar F, et al. Cancer-Associated Fibroblasts Induce Matrix Metalloproteinase-Mediated Cetuximab Resistance in Head and Neck Squamous Cell Carcinoma Cells. Mol Cancer Res 2012;10:1158-68.

204. Müerköster S, Wegehenkel K, Arlt A, et al. Tumor Stroma Interactions Induce Chemoresistance in Pancreatic Ductal Carcinoma Cells Involving Increased Secretion and Paracrine Effects of Nitric Oxide and Interleukin13. Cancer Res 2004;64:1331-7.

205. Shekhar MPV, Santner S, Carolin KA, Tait L. Direct Involvement of Breast Tumor Fibroblasts in the Modulation of Tamoxifen Sensitivity. Am J Pathol 2007;170:1546-60.

206. Wang W, Li Q, Yamada T, et al. Crosstalk to Stromal Fibroblasts Induces Resistance of Lung Cancer to Epidermal Growth Factor Receptor Tyrosine Kinase Inhibitors. Clin Cancer Res 2009;15:6630-8.

207. Bartling B, Hofmann H-S, Silber R-E, Simm A. Differential impact of fibroblasts on the efficient cell death of lung cancer cells induced by paclitaxel and cisplatin. Cancer Biol Ther 2008;7:1250-61.

208. Martinez-Outschoorn UE, Lin Z, Ko Y-H, et al. Understanding the metabolic basis of drug resistance. Cell Cycle 2011;10:2521-8.

209. Liles JS, Arnoletti JP, Kossenkov AV, et al. Targeting ErbB3-mediated stromal-epithelial interactions in pancreatic ductal adenocarcinoma. $\mathrm{Br} \mathrm{J}$ Cancer 2011;105:523-33.

210. Dittmer A, Fuchs A, Oerlecke I, et al. Mesenchymal stem cells and carcinoma-associated fibroblasts sensitize breast cancer cells in 3D cultures to kinase inhibitors. Int J Oncol 2011;39:689-96.

211. Manshouri T, Estrov Z, Quintás-Cardama A, et al. Bone Marrow StromaSecreted Cytokines Protect JAK2V617F-Mutated Cells from the Effects of a JAK2 Inhibitor. Cancer Res 2011;71:3831-40. 
212. Mueller MM, Fusenig NE. Friends or foes - bipolar effects of the tumour stroma in cancer. Nat Rev Cancer 2004;4:839-49.

213. Joyce JA. Therapeutic targeting of the tumor microenvironment. Cancer Cell 2005; 7:513-20.

214. Hurwitz H, Fehrenbacher L, Novotny W, et al. Bevacizumab plus irinotecan, fluorouracil, and leucovorin for metastatic colorectal cancer. $\mathrm{N}$ Engl J Med 2004;350:2335-42.

215. Sandler A, Gray R, Perry MC, et al. Paclitaxel-carboplatin alone or with bevacizumab for non-small-cell lung cancer. N Engl J Med 2006;355:2542-50.

216. Escudier B, Pluzanska A, Koralewski P, et al. Bevacizumab plus interferon alfa-2a for treatment of metastatic renal cell carcinoma: a randomised, double-blind phase III trial. Lancet 2007;370:2103-11.

217. Friedman HS, Prados MD, Wen PY, et al. Bevacizumab alone and in combination with irinotecan in recurrent glioblastoma. J Clin Oncol 2009;27:4733-40.

218. Kreisl TN, Kim L, Moore K, et al. Phase II trial of single-agent bevacizumab followed by bevacizumab plus irinotecan at tumor progression in recurrent glioblastoma. J Clin Oncol 2009;27:740-5.

219. Miller KD, Chap LI, Holmes FA, et al. Randomized Phase III Trial of Capecitabine Compared With Bevacizumab Plus Capecitabine in Patients With Previously Treated Metastatic Breast Cancer. JCO 2005;23:792-9.

220. Miller K, Wang M, Gralow J, et al. Paclitaxel plus bevacizumab versus paclitaxel alone for metastatic breast cancer. N Engl J Med 2007;357:2666-76.

221. Farnebo L, Jedlinski A, Ansell A, et al. Proteins and single nucleotide polymorphisms involved in apoptosis, growth control, and DNA repair predict cisplatin sensitivity in head and neck cancer cell lines. Int J Mol Med 2009;24:549-56.

222. Gupta RA, DuBois RN. Colorectal cancer prevention and treatment by inhibition of cyclooxygenase-2. Nat Rev Cancer 2001;1:11-21. 
223. Sahin IH, Hassan MM, Garrett CR. Impact of non-steroidal antiinflammatory drugs on gastrointestinal cancers: Current state-of-the science. Cancer Lett 2013;

224. Bresalier RS, Sandler RS, Quan H, et al. Cardiovascular events associated with rofecoxib in a colorectal adenoma chemoprevention trial. N Engl J Med 2005;352:1092-102.

225. Jedlinski A, Ansell A, Johansson A-C, Roberg K. EGFR status and EGFR ligand expression influence the treatment response of head and neck cancer cell lines. J Oral Pathol Med 2013;42:26-36.

226. Leutenegger CM, Mislin CN, Sigrist B, Ehrengruber MU, HofmannLehmann R, Lutz H. Quantitative real-time PCR for the measurement of feline cytokine mRNA. Vet Immunol Immunopathol 1999;71:291-305.

227. Wang D, Lippard SJ. Cellular processing of platinum anticancer drugs. Nat Rev Drug Discov 2005;4:307-20.

228. Johansson N, Airola K, Grénman R, Kariniemi AL, Saarialho-Kere U, Kähäri VM. Expression of collagenase-3 (matrix metalloproteinase-13) in squamous cell carcinomas of the head and neck. Am J Pathol 1997;151:499-508.

229. Luukkaa M, Vihinen P, Kronqvist P, et al. Association between high collagenase-3 expression levels and poor prognosis in patients with head and neck cancer. Head Neck 2006;28:225-34.

230. Ii M, Yamamoto H, Adachi Y, Maruyama Y, Shinomura Y. Role of matrix metalloproteinase-7 (matrilysin) in human cancer invasion, apoptosis, growth, and angiogenesis. Exp Biol Med (Maywood) 2006;231:20-7.

231. Pacheco MM, Kowalski LP, Nishimoto IN, Brentani MM. Differential expression of c-jun and c-fos mRNAs in squamous cell carcinoma of the head and neck: associations with uPA, gelatinase $\mathrm{B}$, and matrilysin mRNAs. Head Neck 2002;24:24-32.

232. Strand S, Vollmer P, van den Abeelen L, et al. Cleavage of CD95 by matrix metalloproteinase-7 induces apoptosis resistance in tumour cells. Oncogene 2004;23:3732-6.

233. Mitsiades N, Yu WH, Poulaki V, Tsokos M, Stamenkovic I. Matrix metalloproteinase-7-mediated cleavage of Fas ligand protects tumor cells from chemotherapeutic drug cytotoxicity. Cancer Res 2001;61:577-81. 
234. Mimori K, Yamashita K, Ohta M, et al. Coexpression of Matrix Metalloproteinase-7 (MMP-7) and Epidermal Growth Factor (EGF) Receptor in Colorectal Cancer An EGF Receptor Tyrosine Kinase Inhibitor Is Effective against MMP-7-Expressing Cancer Cells. Clin Cancer Res 2004;10:8243-9.

235. Fingleton B, Vargo-Gogola T, Crawford HC, Matrisian LM. Matrilysin [MMP-7] expression selects for cells with reduced sensitivity to apoptosis. Neoplasia 2001;3:459-68.

236. Oshima G, Wennerberg J, Yamatodani T, et al. Autocrine epidermal growth factor receptor ligand production and cetuximab response in head and neck squamous cell carcinoma cell lines. J Cancer Res Clin Oncol 2012;138:491-9.

237. Modjtahedi H, Styles J, Dean C. The growth-response of human tumor cell lines expressing the EGF receptor to treatment with EGF and or mabs that block ligand-binding. Int J Oncol 1993;3:237.

238. Roepstorff K, Grandal MV, Henriksen L, et al. Differential Effects of EGFR Ligands on Endocytic Sorting of the Receptor. Traffic 2009;10:1115-27.

239. Jones JT, Akita RW, Sliwkowski MX. Binding specificities and affinities of egf domains for ErbB receptors. FEBS Letters 1999;447:227-31.

240. Shirasuna K, Hayashido Y, Sugiyama M, Yoshioka H, Matsuya T. Immunohistochemical localization of epidermal growth factor (EGF) and EGF receptor in human oral mucosa and its malignancy. Virchows Arch A Pathol Anat Histopathol 1991;418:349-53.

241. Hwang RF, Moore T, Arumugam T, et al. Cancer-Associated Stromal Fibroblasts Promote Pancreatic Tumor Progression. Cancer Res 2008;68:918-26.

242. Yamada T, Matsumoto K, Wang W, et al. Hepatocyte Growth Factor Reduces Susceptibility to an Irreversible Epidermal Growth Factor Receptor Inhibitor in EGFR-T790M Mutant Lung Cancer. Clin Cancer Res 2010;16:174-83.

243. Spigel DR, Ervin TJ, Ramlau RA, et al. Randomized Phase II Trial of Onartuzumab in Combination With Erlotinib in Patients With Advanced Non-Small-Cell Lung Cancer. J Clin Oncol 2013; 
244. Landi L, Minuti G, D'Incecco A, Cappuzzo F. Targeting c-MET in the battle against advanced nonsmall-cell lung cancer: Curr Opin Oncol 2013;25:130-6. 